\title{
Numerical Simulation on Impacts of Thickness of Nafion Series Membranes and Relative Humidity on PEMFC Operated at $363 \mathrm{~K}$ and $373 \mathrm{~K}$
}

\author{
Akira Nishimura ${ }^{1, *(D)}$, Kyohei Toyoda ${ }^{1}$, Yuya Kojima ${ }^{1}$, Syogo Ito ${ }^{1}$ and Eric Hu ${ }^{2}$ (D) \\ 1 Division of Mechanical Engineering, Graduate School of Engineering, Mie University, \\ 1577 Kurimamachiya-cho, Tsu 514-8507, Mie, Japan; 421M133@m.mie-u.ac.jp (K.T.); \\ 420M118@m.mie-u.ac.jp (Y.K.); 418110@m.mie-u.ac.jp (S.I.) \\ 2 School of Mechanical Engineering, The University of Adelaide, Adelaide, SA 5005, Australia; \\ eric.hu@adelaide.edu.au \\ * Correspondence: nisimura@mach.mie-u.ac.jp; Tel.: +81-59-231-9747
}

check for updates

Citation: Nishimura, A.; Toyoda, K.; Kojima, Y.; Ito, S.; Hu, E. Numerical Simulation on Impacts of Thickness of Nafion Series Membranes and Relative Humidity on PEMFC Operated at $363 \mathrm{~K}$ and $373 \mathrm{~K}$. Energies 2021, 14, 8256. https://doi.org/ $10.3390 /$ en14248256

Academic Editors: Alexandra M. F. R. Pinto, Rui Ferreira and D. S. Falcão

Received: 11 November 2021 Accepted: 3 December 2021 Published: 8 December 2021

Publisher's Note: MDPI stays neutral with regard to jurisdictional claims in published maps and institutional affiliations.

Copyright: (c) 2021 by the authors. Licensee MDPI, Basel, Switzerland. This article is an open access article distributed under the terms and conditions of the Creative Commons Attribution (CC BY) license (https:// creativecommons.org/licenses/by/ $4.0 /)$.

\begin{abstract}
The purpose of this study is to understand the impact of the thickness of Nafion membrane, which is a typical polymer electrolyte membrane (PEM) in Polymer Electrolyte Membrane Fuel Cells (PEMFCs), and relative humidity of supply gas on the distributions of $\mathrm{H}_{2}, \mathrm{O}_{2}, \mathrm{H}_{2} \mathrm{O}$ concentration and current density on the interface between a Nafion membrane and anode catalyst layer or the interface between a Nafion membrane and cathode catalyst layer. The effect of the initial temperature of the cell $\left(T_{\text {ini }}\right)$ is also investigated by the numerical simulation using the 3D model by COMSOL Multiphysics. As a result, the current density decreases along with the gas flow through the gas channel irrespective of the Nafion membrane thickness and $T_{\text {ini, }}$, which can be explained by the concentration distribution of $\mathrm{H}_{2}$ and $\mathrm{O}_{2}$ consumed by electrochemical reaction. The molar concentration of $\mathrm{H}_{2} \mathrm{O}$ decreases when the thickness of Nafion membrane increases, irrespective of $T_{\mathrm{ini}}$ and the relative humidity of the supply gas. The current density increases with the increase in relative humidity of the supply gas, irrespective of the Nafion membrane thickness and $T_{\text {ini }}$. This study recommends that a thinner Nafion membrane with well-humidified supply gas would promote high power generation at the target temperature of $363 \mathrm{~K}$ and $373 \mathrm{~K}$.
\end{abstract}

Keywords: PEMFC; higher temperature operation than usual; numerical simulation; thickness of Nafion membrane; relative humidity of supply gas; mass and current density distribution

\section{Introduction}

The polymer electrolyte membrane fuel cell (PEMFC) is one of the promising fuel cell technologies which can use $\mathrm{H}_{2}$ as a fuel for co-generation system and vehicles. Recently, it has been conceived that $\mathrm{H}_{2}$ could be one procedure to realize the target of zero $\mathrm{CO}_{2}$ emissions by 2050 in Japan. Therefore, it is important to develop the efficient PEMFC system by 2050. It is important to develop the efficient PEMFC system as well as green $\mathrm{H}_{2}$ production in order to achieve the net target, i.e., a virtually zero $\mathrm{CO}_{2}$ emission in Japan by 2050. According to the Japanese New Energy and Industry Technology Development Organization (NEDO) road map 2017 [1], a PEMFC system is required to be operated at $363 \mathrm{~K}$ and $373 \mathrm{~K}$ for stationary and mobility applications, respectively, from 2020 to 2025. However, the normal PEMFC, which uses a Nafion membrane, is usually operated within a lower temperature range, between $333 \mathrm{~K}$ and $353 \mathrm{~K}$ [2,3]. If PEMFC is operated at a higher temperature than usual, the following advantages can be obtained: (1) promoting electrochemical kinetics in both electrodes, (2) reducing the cooling system for automobile applications due to an increase in the temperature difference between the PEMFC stack and coolant, and (3) endurance enhancement to $\mathrm{CO}$ in lower quality reformed $\mathrm{H}_{2}$ [4]. However, operating the PEMFC system at a higher temperature would present challenges, including: (1) degradation of Nafion membranes; (2) catalyst elution; (3) uneven distributions of gas 
flow, pressure, temperature, voltage and current in a cell of PEMFC. It is necessary to solve them in order to commercialize the PEMFC system operated at a higher temperature [5]. In addition, it is also believed that the temperature distribution influences the phase change of $\mathrm{H}_{2} \mathrm{O}$ and can influence the performance of the polymer electrolyte membrane (PEM), fuel and oxidant flows in gas diffusion layer (GDL) and catalyst layer at high temperatures. Consequently, it is necessary to analyze the heat and mass transfer mechanism in a cell of PEMFC in order to improve the power generation performance and achieve a longer operation time.

According to the literature on high-temperature PEMFC operated over $373 \mathrm{~K}$, newly developed membranes which can be used at a high temperature include polybenzimidazolebased membrane [6] and bulky N-heterocyclic group functionalized poly (terphenyl piperidinium) membrane [7]. Regarding the development of new electrode, polytetrafluoroethylene (PTFE) binder dispersion [8] and 3D numerical simulation for the optimization of electrode thickness [9] have been reported. In addition, the optimization of the flow channel of a gas separator [10] and multi-objective optimization of operating conditions [11] are popular topics being studied. Mass transport phenomena in a cell such as distributions of $\mathrm{H}_{2}, \mathrm{O}_{2}$, and $\mathrm{H}_{2} \mathrm{O}$ concentration are also being investigated [12-14]. The temperature distribution on the back of the separator and the interface between PEM and the cathode catalyst layer has been investigated experimentally $[15,16]$ and numerically $[17,18]$, respectively, by the authors. Though the current density and temperature distribution were studied experimentally [19] and numerically [20] at the same time, there have been no reports investigating the distribution of $\mathrm{H}_{2}, \mathrm{O}_{2}, \mathrm{H}_{2} \mathrm{O}$ concentration and current density on the interface between PEM and the anode catalyst layer, where the $\mathrm{H}_{2}$ oxidation reaction occurs or the interface between PEM and the cathode catalyst layer where the $\mathrm{O}_{2}$ reduction reaction occurs. In addition, the previous numerical research [12-14] used the contour figure qualitatively. It is not enough to understand the mechanism of electrochemical reaction deciding the power generation performance of PEMFC. It is important to understand the characteristics on the interface between PEM and the anode catalyst layer where the $\mathrm{H}_{2}$ oxidization reaction occurs and the interface between PEM and the cathode catalyst layer where the $\mathrm{O}_{2}$ reduction reaction occurs quantitatively. Therefore, the analysis of these distributions is important to understand the electrochemical reaction and power generation characteristics of PEMFC. Therefore, the purpose of this study is to clarify the distributions of $\mathrm{H}_{2}, \mathrm{O}_{2}, \mathrm{H}_{2} \mathrm{O}$ concentration and the current density on the interface between the Nafion membrane, which is used as a typical PEM, and the anode catalyst layer or the interface between the Nafion membrane and cathode catalyst layer under a higher-temperature operation condition than usual. Some new membranes, e.g., polybenzimidazole-based membrane [6], have recently been developed for the high-temperature operation of PEMFC. However, it is easy to apply and commercialize the PEMFC system if the Nafion membrane can be used at a high temperature such as $363 \mathrm{~K}$ and $373 \mathrm{~K}$. Numerical simulation using a 3D model by multi-physics simulation software COMSOL Multiphysics has also been carried out to achieve the aim of this study. In addition, the impact of the Nafion membrane thickness on these distributions has also been investigated. When the thinner Nafion membrane is used, lower Ohmic resistance as well as a higher proton flux ratio and back diffusion can be obtained [21-23]. Therefore, it is also important to investigate the effect of the Nafion membrane thickness on the distributions of $\mathrm{H}_{2}, \mathrm{O}_{2}$, and $\mathrm{H}_{2} \mathrm{O}$ concentration and current density on the interface between the Nafion membrane and anode catalyst layer or the interface between the Nafion membrane and cathode catalyst layer.

\section{Numerical Modeling}

\subsection{Model Description and Governing Equations}

This study has conducted the numerical analysis using a 3D model by multi-physics simulation software COMSOL Multiphysics. It has the simulation code for PEMFC composed of a continuity equation, the Brinkmann equation, considering the momentum transfer; the Maxwell-Stefan equation, considering the diffusion transfer; and the Butler- 
Volmer equation, considering the electrochemical reaction. This simulation code has been validated well by many previous studies [12,24-26].

The continuity equation considering the gas species in porous media such as the catalyst layer, micro porous layer (MPL), and GDL as well as in the gas channel is expressed as follows:

$$
\frac{\partial}{\partial t}\left(\varepsilon_{p} \rho\right)+\nabla \cdot(\rho \vec{u})=Q_{m}
$$

where $\varepsilon_{p}$ is the porosity ( ), $\rho$ is the density $\left(\mathrm{kg} / \mathrm{m}^{3}\right), \vec{u}$ is the velocity vector $(\mathrm{m} / \mathrm{s}), Q_{m}$ is the mass source term $\left(\mathrm{kg} /\left(\mathrm{m}^{3} \mathrm{~s}\right)\right)$, and $t$ is the time (s). The relationship between the pressure and gas flow velocity, which is solved in porous media such as the catalyst layer, MPL, and GDL, as well as in the gas channel, can be expressed by the following Brinkmann equation:

$$
\begin{gathered}
\frac{\rho}{\varepsilon_{p}}\left(\frac{\partial \vec{u}}{\partial t}+(\vec{u} \cdot \nabla) \frac{\vec{u}}{\varepsilon_{p}}\right) \\
=-\nabla p+\nabla \cdot\left[\frac{1}{\varepsilon_{p}}\left\{\mu\left(\nabla \vec{u}+(\nabla \vec{u})^{T}\right)-\frac{2}{3} \mu(\nabla \cdot \vec{u}) \vec{I}\right\}\right]-\left(\kappa^{-1} \mu+\frac{Q_{m}}{\varepsilon_{p}^{2}}\right) \vec{u}+\vec{F}
\end{gathered}
$$

where $p$ is the pressure (Pa), $\mu$ is the viscosity (Pa s), $\vec{I}$ is the unit vector( $), \kappa$ is the permeability $\left(\mathrm{m}^{2}\right)$, and $\vec{F}$ is the force vector $\left(\mathrm{kg} /\left(\mathrm{m}^{2} \cdot \mathrm{s}^{2}\right)\right)$, e.g., gravity.

Mass transfer considering the diffusion, ion transfer, and convection transfer can be expressed by the following Maxwell-Stefan equation:

$$
\begin{gathered}
\vec{N}_{i}=-D_{i} \nabla C_{i}-z_{i} u_{m, i} F C_{i} \nabla \varphi_{l}+C_{i} \vec{u}=\vec{J}_{i}+C_{i} \vec{u} \\
\frac{\partial C_{i}}{\partial t}+\nabla \cdot \vec{N}_{i}=R_{i, t o t}
\end{gathered}
$$

where $\vec{N}_{i}$ is the vector of the molar flow rate on the interface between PEM and electrode $\left(\mathrm{mol} /\left(\mathrm{m}^{2} \mathrm{~s}\right)\right), D_{i}$ is the diffusion coefficient $\left(\mathrm{m}^{2} / \mathrm{s}\right), C_{i}$ is the concentration of ion $i\left(\mathrm{~mol} / \mathrm{m}^{3}\right)$, $z_{i}$ is the valence of ion ()$, u_{m, i}$ is the mobility of ion $i((\mathrm{~s} \mathrm{~mol}) / \mathrm{kg}), F$ is the Faraday constant $(\mathrm{C} / \mathrm{mol}), \varphi_{l}$ is the electrical potential of liquid [27] $(\mathrm{V}), \vec{J}$ is the molar flow rate of the convection transfer $\left(\mathrm{mol} /\left(\mathrm{m}^{2} \mathrm{~s}\right)\right)$, and $R_{i, t o t}$ is the reaction rate of species $\left(\mathrm{mol} /\left(\mathrm{m}^{3} \mathrm{~s}\right)\right)$.

The electrochemical reaction is calculated following Butler-Volmer equation:

$$
\begin{gathered}
i=i_{0}\left\{\exp \left(\frac{\alpha_{a} F \eta}{R T}\right)-\exp \left(\frac{-\alpha_{c} F \eta}{R T}\right)\right\} \\
\eta=\varphi_{s}-\varphi_{l}-E_{e q}
\end{gathered}
$$

where $i$ is the current density $\left(\mathrm{A} / \mathrm{m}^{2}\right), i_{0}$ is the exchange current density $\left(\mathrm{A} / \mathrm{m}^{2}\right), \alpha_{a}$ is the charge transfer coefficient at anode ( ), $\eta$ is the activation over-potential [27] (V), $R$ is the gas constant $(\mathrm{J} /(\mathrm{mol} \mathrm{K})), T$ is the temperature $(\mathrm{K}), \alpha_{c}$ is the charge transfer coefficient at cathode ( ), $\varphi_{s}$ is the electrical potential of solid [27] (V), $E_{e q}$ is the equilibrium electric potential [27] (V).

Figure 1 illustrates 3D model of single cell of PEMFC. This structure follows the commercialized single cell used in the previous experimental study [16]. In this model, the outside of the roof of gas separator at anode and cathode sides are omitted. This single cell has a gas separator having a serpentine flow channel which consists not only of five gas channels with the width of $1.0 \mathrm{~mm}$ and depth of $1.0 \mathrm{~mm}$ but also a rib with a width of $1.0 \mathrm{~mm}$. Table 1 lists the geometrical parameters of the 3D model used in this study. Nafion 115, Nafion NRE-212, and Nafion NRE-211, whose thicknesses are $127 \mu \mathrm{m}, 51 \mu \mathrm{m}$, and $25 \mu \mathrm{m}$, respectively, have been investigated to assess the impact of the thickness of the Nafion membrane on the distributions of $\mathrm{H}_{2}, \mathrm{O}_{2}$, and $\mathrm{H}_{2} \mathrm{O}$ concentrations and the current density. Physical parameters and operation conditions for numerical simulation in this study are listed in Tables 2 and 3, respectively. $T_{\text {ini }}$ is changed by $353 \mathrm{~K}, 363 \mathrm{~K}$, and $373 \mathrm{~K}$. This study has conducted the numerical simulation at $T_{\mathrm{ini}}=353 \mathrm{~K}$ showing 
the characteristics at a standard operation temperature to compare the characteristics at a higher temperature. The relative humidity of supply gas at the anode and cathode is changed by $40 \% \mathrm{RH}$ and $80 \% \mathrm{RH}$, respectively. The flow rate of supply gas is set at the stoichiometric ratio of 1.5 , where the volume flow rate of supply gas at the anode and cathode is $0.210 \mathrm{NL} / \mathrm{min}$ and $0.105 \mathrm{NL} / \mathrm{min}$, respectively. The stoichiometric ratio of 1.0 for the flow rate of supply gas can be defined by Equation (7).

$$
C_{H 2}=\frac{I}{z_{H 2} F}
$$

where $C_{H 2}$ is the molar flow rate of consumed $\mathrm{H}_{2}(\mathrm{~mol} / \mathrm{s}), I$ is the loaded current (A) and $z_{H 2}$ is the electrons moles exchanged in the reaction $(=2)() . C_{H 2}$ is the molar flow rate corresponding to the stoichiometric ratio of 1.0. The $\mathrm{C}_{\mathrm{O} 2}$ is the molar flow rate of consumed $\mathrm{O}_{2}\left(\mathrm{~mol} / \mathrm{s}\right.$ ), which is a half of $C_{H 2}$ (which can be defined by Equation (8)).

$$
\mathrm{H}_{2}+1 / 2 \mathrm{O}_{2}=\mathrm{H}_{2} \mathrm{O}
$$

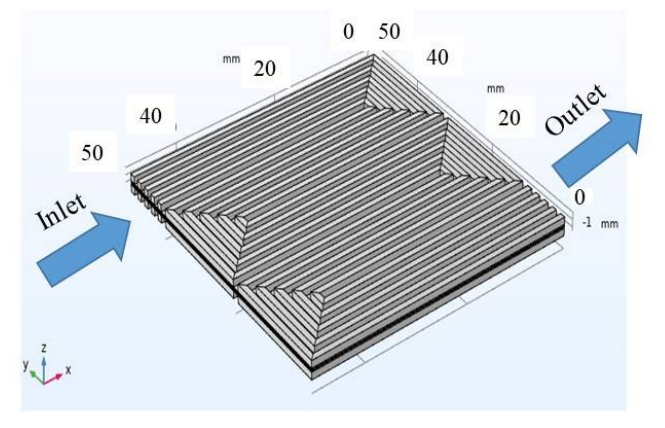

$<$ Bird's eye view $>$



$<$ Top view $>$

Figure 1. Three-dimensional model for numerical simulation.

Table 1. Geometrical parameters of 3D model for numerical simulation [22,28-31].

\begin{tabular}{ccc}
\hline Components & Size & Characteristics \\
\hline PEM & $50.0 \mathrm{~mm} \times 50.0 \mathrm{~mm} \times 0.127 \mathrm{~mm}$ (for Nafion & Nafion 115, Nafion NRE-212, Nafion \\
& $115), 0.051 \mathrm{~mm}($ for Nafion NRE-212) and & NRE-211 (manufactured by Du Pont Corp.) \\
Catalyst layer & $0.025 \mathrm{~mm}($ for Nafion NRE-211) & Pt/C (Pt: $20 \mathrm{wt} \%)$ \\
MPL & $50.0 \mathrm{~mm} \times 50.0 \mathrm{~mm} \times 0.01 \mathrm{~mm}$ & PTFE + carbon black \\
GDL & $50.0 \mathrm{~mm} \times 50.0 \mathrm{~mm} \times 0.003 \mathrm{~mm}$ & TGP-H-060 (manufactured by Toray Corp.) \\
Gas separator & $50.0 \mathrm{~mm} \times 50.0 \mathrm{~mm} \times 0.19 \mathrm{~mm}$ & Carbon graphite, serpentine \\
& $50.0 \mathrm{~mm} \times 50.0 \mathrm{~mm} \times 2.00 \mathrm{~mm}$ (thickness of & \\
\hline
\end{tabular}

Table 2. Physical parameters for numerical simulation in this study.

\begin{tabular}{cc}
\hline Parameter Name & Value \\
\hline Density of $\mathrm{H}_{2}\left(\mathrm{~kg} / \mathrm{m}^{3}\right)$ & $7.10 \times 10^{-2}(353 \mathrm{~K}), 6.89 \times 10^{-2}(363 \mathrm{~K}), 6.69 \times 10^{-2}(373 \mathrm{~K})[32]$ \\
Density of $\mathrm{O}_{2}\left(\mathrm{~kg} / \mathrm{m}^{3}\right)$ & $1.11(353 \mathrm{~K}), 1.08(363 \mathrm{~K}), 1.05(373 \mathrm{~K})[32]$ \\
Density of $\mathrm{H}_{2} \mathrm{O}\left(\mathrm{kg} / \mathrm{m}^{3}\right)$ & $2.95 \times 10^{-1}(353 \mathrm{~K}), 4.26 \times 10^{-1}(363 \mathrm{~K}), 6.01 \times 10^{-1}(373 \mathrm{~K})[32]$ \\
Viscosity of $\mathrm{H}_{2}(\mathrm{~Pa} \mathrm{~s})$ & $9.96 \times 10^{-6}(353 \mathrm{~K}), 1.02 \times 10^{-5}(363 \mathrm{~K}), 1.03 \times 10^{-5}(373 \mathrm{~K})[32]$ \\
Viscosity of $\mathrm{O}_{2}(\mathrm{~Pa} \mathrm{~s})$ & $2.35 \times 10^{-5}(353 \mathrm{~K}), 2.40 \times 10^{-5}(363 \mathrm{~K}), 2.45 \times 10^{-5}(373 \mathrm{~K})[32]$ \\
Viscosity of $\mathrm{H}_{2} \mathrm{O}(\mathrm{Pa} \mathrm{s})$ & $1.16 \times 10^{-5}(353 \mathrm{~K}), 1.19 \times 10^{-5}(363 \mathrm{~K}), 1.23 \times 10^{-5}(373 \mathrm{~K})[32]$ \\
Binary diffusion coefficient between $\mathrm{H}_{2}$ and $\mathrm{H}_{2} \mathrm{O}\left(\mathrm{m}^{2} / \mathrm{s}\right)$ & $9.27 \times 10^{-5}[33]$ \\
Binary diffusion coefficient between $\mathrm{O}_{2}$ and $\mathrm{H}_{2} \mathrm{O}\left(\mathrm{m}^{2} / \mathrm{s}\right)$ & $3.57 \times 10^{-5}[33]$ \\
\hline
\end{tabular}


Table 2. Cont

\begin{tabular}{cc}
\hline Parameter Name & Value \\
\hline Porosity of catalyst layer () & $0.78[17,22,29-31]$ \\
Permeability of catalyst layer $\left(\mathrm{m}^{2}\right)$ & $8.69 \times 10^{-12}[17,22,29-31]$ \\
Porosity of MPL ( ) & $0.60[17,22,29-31]$ \\
Permeability of MPL $\left(\mathrm{m}^{2}\right)$ & $1.00 \times 10^{-13}[17,22,29-31]$ \\
Porosity of GDL ( ) & $0.78[17,22,29-31]$ \\
Permeability of GDL $\left(\mathrm{m}^{2}\right)$ & $8.69 \times 10^{-12}[17,22,29-31]$ \\
Conductivity of catalyst layer $(\mathrm{S} / \mathrm{m})$ & $10[34]$ \\
Conductivity of MPL $(\mathrm{S} / \mathrm{m})$ & $53[35]$ \\
Conductivity of GDL $(\mathrm{S} / \mathrm{m})$ & $1000[36]$ \\
Conductivity of Nafion series mode reference equilibrium potential $(\mathrm{V})$ & $1250[37]$ \\
Cathode reference equilibrium potential $(\mathrm{V})$ & 0 \\
Anode reference exchange current density $\left(\mathrm{A} / \mathrm{m}^{2}\right)$ & 1.229 \\
Cathode reference exchange current density $\left(\mathrm{A} / \mathrm{m}^{2}\right)$ & $1000[38]$ \\
Anode charge transfer coefficient () & $1[38]$ \\
Cathode charge transfer coefficient () & $0.5[39]$ \\
\hline
\end{tabular}

Table 3. Operation conditions for numerical simulation in this study.

\begin{tabular}{ccc}
\hline Each Condition & \multicolumn{2}{c}{ Value } \\
\hline The initial temperature of cell $\left(T_{\text {ini }}\right)(\mathrm{K})$ & \multicolumn{2}{c}{$353,363,373$} \\
Cell voltage $(\mathrm{V})$ & Experimental data are used $[16,17]$ \\
Supply gas condition & Anode & Cathode \\
Gas type & $\mathrm{H}_{2}$ & $\mathrm{O}_{2}$ \\
Temperature of supply gas at inlet $(\mathrm{K})$ & $353,363,373$ & $353,363,373$ \\
Relative humidity of supply gas $(\% \mathrm{RH})$ & 40,80 & 40,80 \\
Pressure of supply gas at inlet $($ absolute $(\mathrm{MPa})$ & 0.4 & 0.4 \\
Flow rate of supply gas at inlet $[\mathrm{NL} / \mathrm{min}]$ & $0.210(1.5)$ & $0.105(1.5)$ \\
(Stoichiometric ratio ()$)$ & &
\end{tabular}

In this study, $\mathrm{O}_{2}$ is adopted as the cathode gas. In the near future, it can be expected that $\mathrm{H}_{2}$ will be produced from renewable energy via $\mathrm{H}_{2} \mathrm{O}$ electrolyzer mainly in order to realize a zero- $\mathrm{CO}_{2}$-emission society. After the production of $\mathrm{H}_{2}$ by $\mathrm{H}_{2} \mathrm{O}$ electrolysis, $\mathrm{O}_{2}$ is also produced as a by-product. This study suggests that not only $\mathrm{H}_{2}$ but also $\mathrm{O}_{2}$ produced from $\mathrm{H}_{2} \mathrm{O}$ electrolysis are used for PEMFC. The total system consisting of renewable energy, $\mathrm{H}_{2} \mathrm{O}$ electrolyzer, and PEMFC can be operated effectively by using $\mathrm{O}_{2}$. In addition, if we use $\mathrm{O}_{2}$ as a cathode gas, we can obtain a higher current density on the interface between PEM and the catalyst layer, especially under the rib, compared to the case using air [28]. This is due to the decrease in over-potential by the increase in the concentration of $\mathrm{O}_{2}$. Therefore, it can be expected that higher power generation performance is obtained by using $\mathrm{O}_{2}$. They are the reasons why this study adopts pure $\mathrm{O}_{2}$ instead of air.

\subsection{Model Assumption}

This study considers the following assumptions:

(i) The distributions of the inlet gas flow rate at the anode side and cathode side are uniform, respectively.

(ii) The pressure of the outlet of the gas channel is the atmospheric pressure.

(iii) No slip on the gas channel wall excluding the inlet and the outlet of the gas channel is considered.

(iv) The cell voltage obtained by the power generation experiment is set at the cathode electrode and the earth ground is set at the anode electrode. The in-plane distribution of cell voltage at the cathode electrode is uniform.

(v) Reactant gases are treated as an ideal gas and incompressible Newton fluid. 
(vi) $\mathrm{H}_{2} \mathrm{O}$ is treated as a vapor.

(vii) The cell temperature is uniform and the outside boundary of the 3D model is set at $T_{\text {ini. }}$.

(viii) The effective porosity and the permeability of the porous media are isotropic. The conductivity in the porous media is also isotropic.

The impact of the Nafion membrane thickness, $T_{\text {ini }}$, and relative humidity of the supply gas on the distributions of the molar concentration of $\mathrm{H}_{2}, \mathrm{O}_{2}$, and $\mathrm{H}_{2} \mathrm{O}$ and current the density on the interface between the Nafion membrane and anode catalyst layer or the interface between the Nafion membrane and cathode catalyst layer has been investigated, considering the above-described equations and parameters as well as the assumptions.

\section{Results and Discussion}

3.1. In-Plane Distribution of Mass and Current Density on the Interface between Nafion Membrane and Anode Catalyst Layer or the Interface between Nafion Membrane and Cathode Catalyst Layer

Figure 2 shows the comparison of the in-plane molar concentration distribution of $\mathrm{H}_{2}$ on the interface between the Nafion membrane and anode catalyst layer with a different Nafion membrane and $T_{\mathrm{ini}}$ for the relative humidity of the supply gas of the anode of $80 \% \mathrm{RH}$ and cathode of $80 \% \mathrm{RH}$ (A $80 \% \mathrm{RH} \& \mathrm{C} 80 \% \mathrm{RH})$. Figures $3-5$ show the comparisons of in-plane molar concentration distribution of $\mathrm{O}_{2}$ and $\mathrm{H}_{2} \mathrm{O}$ and in-plane distribution of the current density on the interfaces, respectively.

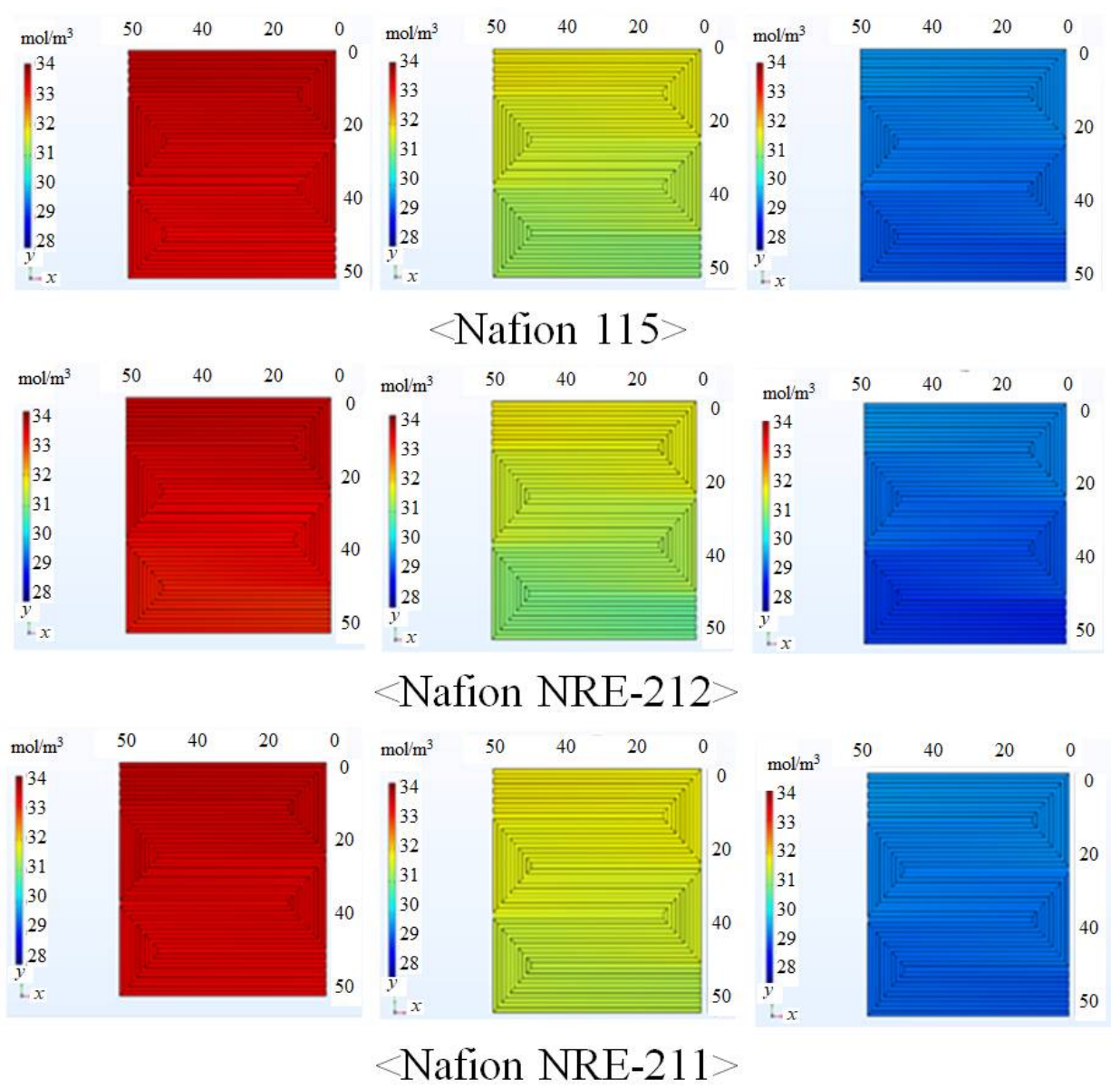

Figure 2. Comparison of in-plane molar concentration distribution of $\mathrm{H}_{2}$ on the interface between Nafion membrane and anode catalyst layer among different Nafion membranes and $T_{\text {ini }}$ (A80\%RH\&C80\%RH; left: $353 \mathrm{~K}$, center: $363 \mathrm{~K}$, right: $373 \mathrm{~K}$ ). 

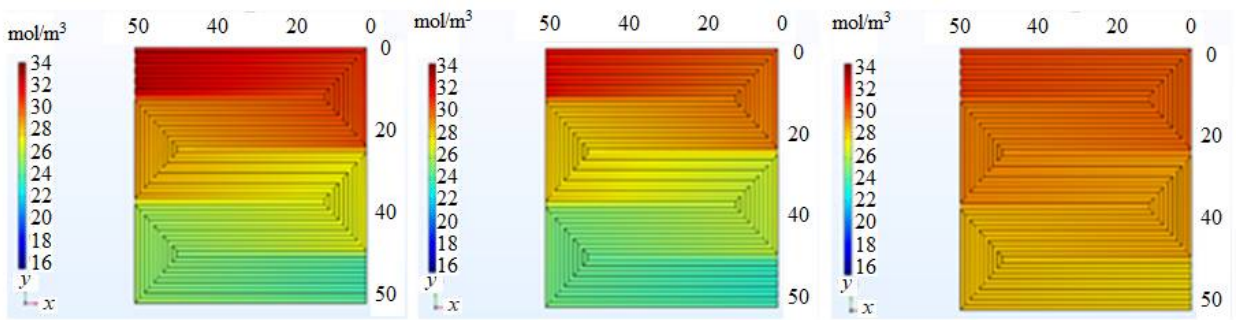

$<$ Nafion 115>
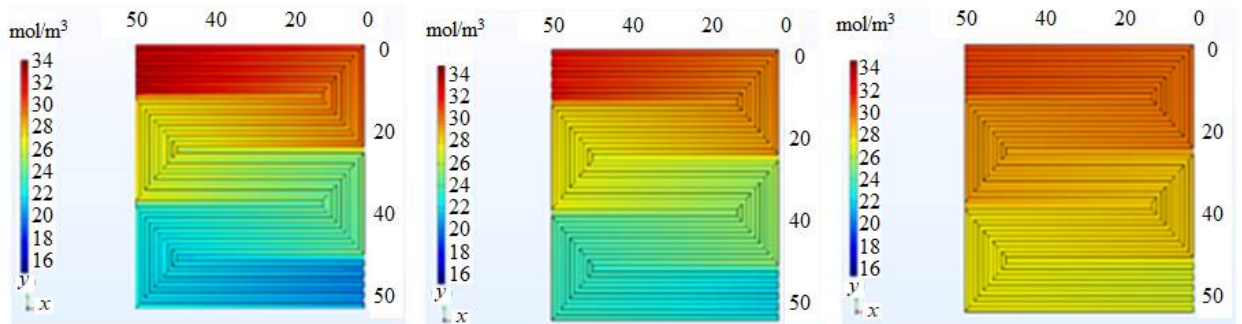

\section{$<$ Nafion NRE-212>}
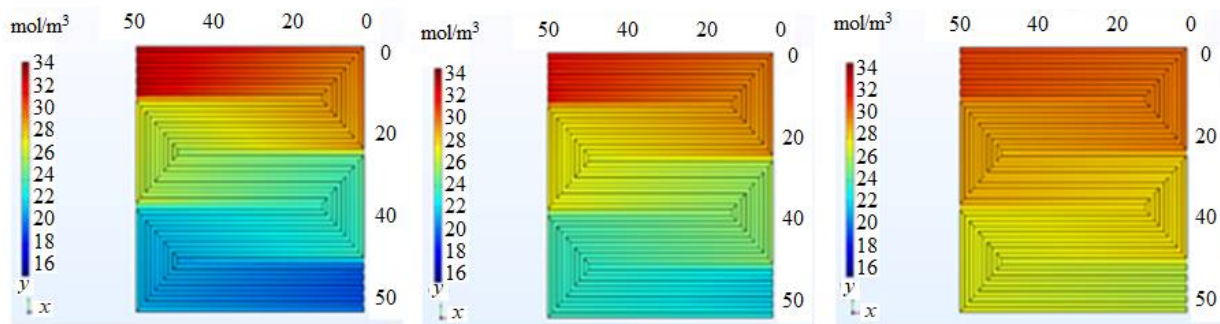

$<$ Nafion NRE-211 $>$

Figure 3. Comparison of in-plane molar concentration distribution of $\mathrm{O}_{2}$ on the interface between Nafion membrane and cathode catalyst layer among different Nafion membranes and $T_{\text {ini }}$ (A80\%RH\&C80\%RH; left: $353 \mathrm{~K}$, center: $363 \mathrm{~K}$, right: $373 \mathrm{~K}$ ).
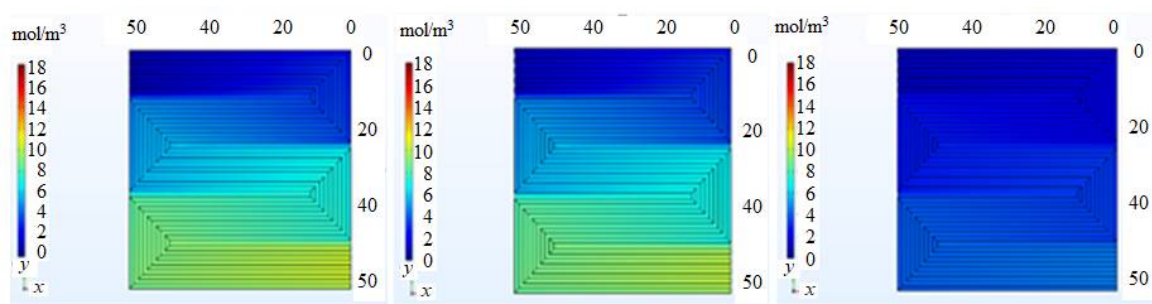

\section{$<$ Nafion 115>}
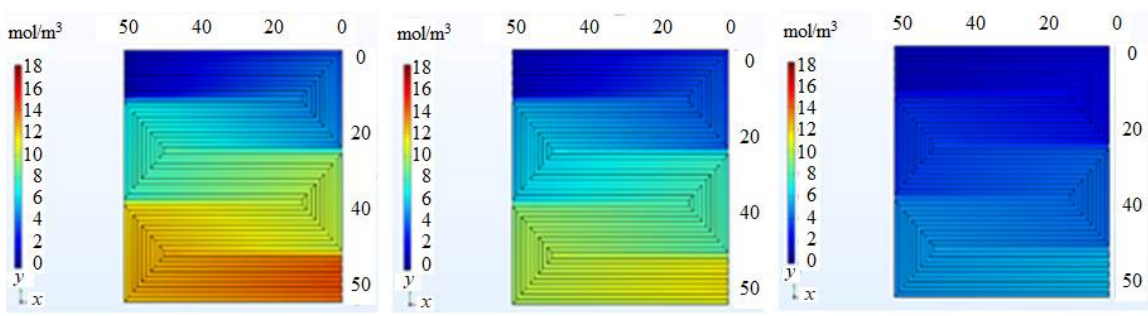

$<$ Nafion NRE-212>

Figure 4. Cont. 

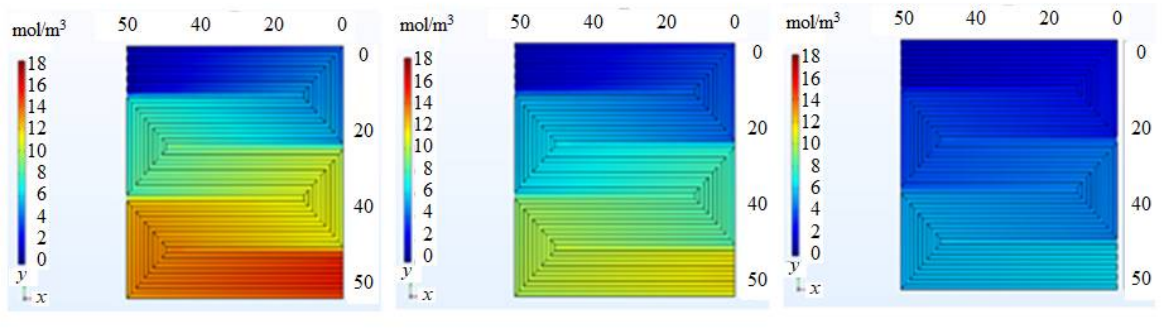

\section{$<$ Nafion NRE-211>}

Figure 4. Comparison of in-plane molar concentration distribution of $\mathrm{H}_{2} \mathrm{O}$ on the interface between Nafion membrane and cathode catalyst layer among different Nafion membranes and $T_{\text {ini }}$ (A80\%RH\&C80\%RH; left: $353 \mathrm{~K}$, center: $363 \mathrm{~K}$, right: $373 \mathrm{~K}$ ).
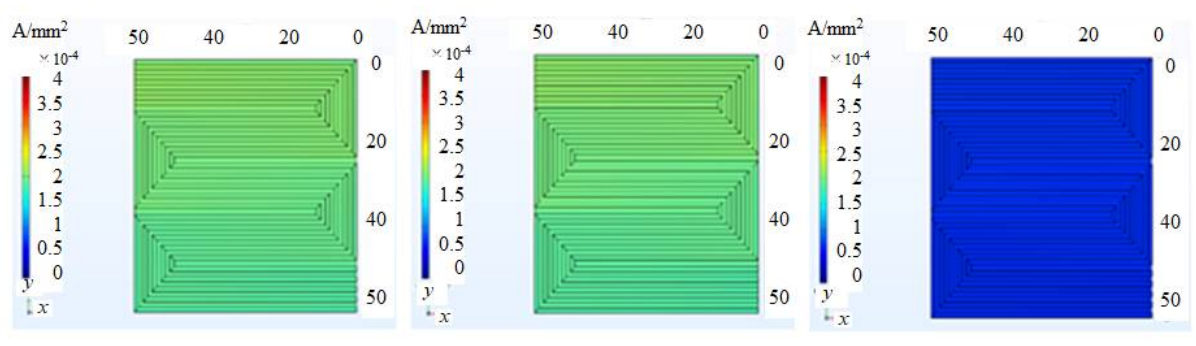

\section{$<$ Nafion 115 $>$}


\section{$<$ Nafion NRE-212 $>$}
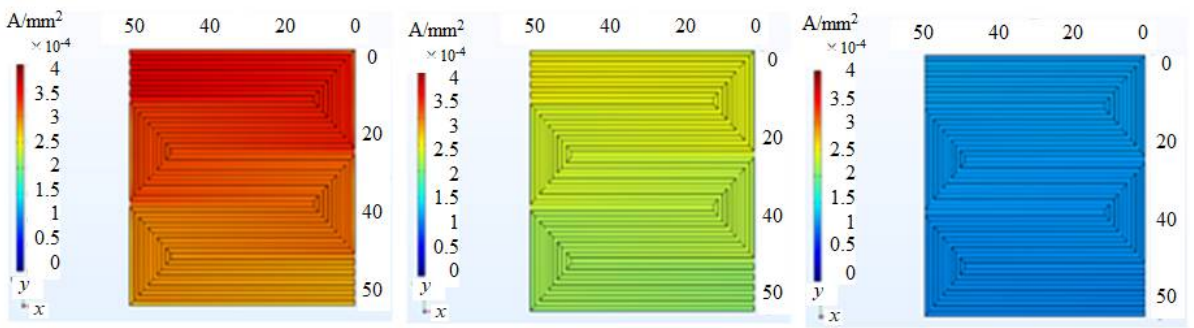

\section{$<$ Nafion NRE-211>}

Figure 5. Comparison of in-plane distribution of current density on the interface between Nafion membrane and cathode catalyst layer among different Nafion membranes and $T_{\text {ini }}$ (A80\%RH\&C80\%RH; left: $353 \mathrm{~K}$, center: $363 \mathrm{~K}$, right: $373 \mathrm{~K}$ ).

According to Figure 2, it is found that the molar concentration of $\mathrm{H}_{2}$ decreases along with the gas flow through the gas channel irrespective of the Nafion membrane thickness and $T_{\text {ini }}$ due to the uniform consumption rate of $\mathrm{H}_{2}$ caused by the high permeability through porous media [12]. In addition, it is known that the molar concentration of $\mathrm{H}_{2}$ decreases more with the increase in $T_{\text {ini, }}$, irrespective of the Nafion membrane thickness. The molar concentration is defined by dividing the molar quantity of gas species by its volume. Since the gas volume increases when $T_{\text {ini }}$ increases, the molar concentration of $\mathrm{H}_{2}$ would decrease with the increase in $T_{\text {ini. }}$. 
It is seen from Figure 3 that the molar concentration of $\mathrm{O}_{2}$ decreases along with the gas flow through the gas channel irrespective of the Nafion membrane thickness and $T_{\text {ini. }}$. It is found that the $\mathrm{O}_{2}$ reduction reaction progresses along with the gas flow through the gas channel. According to Figure 3, the amount of $\mathrm{O}_{2}$ consumption from the inlet to the outlet is the largest at $T_{\text {ini }}=353 \mathrm{~K}$, irrespective of the Nafion membrane thickness. The kinetics of the catalyst are faster with the increase in temperature, while the relative humidity influences the performance of the $\mathrm{O}_{2}$ reduction reaction occurring on the ionomer in the cathode catalyst layer [40]. There is the optimum $\mathrm{H}_{2} \mathrm{O}$ saturation of ionomer in the cathode catalyst layer. On the other hand, the proton conductivity of the Nafion membrane is influenced by the temperature and relative humidity. According to the literature [41,42], the proton conductivity of the Nafion membrane increases with the increase in temperature as well as the increase in relative humidity. Since the saturation pressure of $\mathrm{H}_{2} \mathrm{O}$ vapor increases with the temperature exponentially [43], it is easy to dehydrate the Nafion membrane at $T_{\text {ini }}=373 \mathrm{~K}$ compared to $T_{\text {ini }}=353 \mathrm{~K}$, resulting in the proton conductivity of the Nafion membrane decreasing at $T_{\mathrm{ini}}=373 \mathrm{~K}$. If the proton conductivity of the Nafion membrane decreases, the performance of the $\mathrm{O}_{2}$ reduction reaction drops due to a lack of proton. In addition, since the hydration of the Nafion membrane is not enough at $T_{\text {ini }}=373 \mathrm{~K}$, the high $\mathrm{O}_{2}$ partial pressure is needed to progress the $\mathrm{O}_{2}$ reduction reaction [43]. Consequently, it is thought that the amount of $\mathrm{O}_{2}$ consumption decreases at $T_{\text {ini }}=373 \mathrm{~K}$. The proton conductivity of the Nafion membrane increases when the temperature increases, even at a temperature above $373 \mathrm{~K}$ [40]. However, we have to consider the degradation of the Nafion membrane under the dehydrated condition [44]. Therefore, it is a challenging issue to control the humidification of the Nafion membrane at a temperature above $373 \mathrm{~K}$.

It is seen from Figure 4 that the molar concentration of $\mathrm{H}_{2} \mathrm{O}$ increases along with the gas flow through the gas channel, irrespective of the Nafion membrane thickness and $T_{\text {ini. }}$. This result matches with Figure 3 from the viewpoint of the $\mathrm{O}_{2}$ reduction reaction which produces $\mathrm{H}_{2} \mathrm{O}$ at the cathode. According to Figure 4, the amount of $\mathrm{H}_{2} \mathrm{O}$ produced from the inlet to the outlet is the largest at $T_{\text {ini }}=353 \mathrm{~K}$, irrespective of the Nafion membrane thickness. The reason why this result is obtained can be explained by the above discussion in Figure 3.

According to Figure 5, the current density decreases along with the gas flow through the gas channel, irrespective of the Nafion membrane thickness and $T_{\text {ini. }}$. The molar concentrations of $\mathrm{H}_{2}$ and $\mathrm{O}_{2}$ are the highest at the inlet, respectively, and they decrease along with the gas flow through the gas channel, as shown in Figures 2 and 3 , indicating that the electrochemical reaction progresses along with the gas flow through the gas channel. In addition, the current density is the largest at $T_{\text {ini }}=353 \mathrm{~K}$ among different $T_{\text {ini }}$. Moreover, it is evident that the current density decreases with an increase in the thickness of the Nafion membrane. The authors of this study argue that we have to consider the kinetics of catalyst as well as proton conductivity of Nafion membrane for the discussion of this phenomena. The kinetics of the catalyst are faster with an increase in temperature, while the relative humidity influences the performance of the $\mathrm{O}_{2}$ reduction reaction occurring on the ionomer in the cathode catalyst layer [40]. There is an optimum $\mathrm{H}_{2} \mathrm{O}$ saturation of ionomer in the cathode catalyst layer. On the other hand, the proton conductivity of the Nafion membrane is influenced by the temperature and relative humidity. According to the literature [41,42], the proton conductivity of the Nafion membrane increases with the increase in temperature as well as the increase in relative humidity. Since the saturation pressure of $\mathrm{H}_{2} \mathrm{O}$ vapor exponentially increases with the temperature [43], it is easy to dehydrate the Nafion membrane at $T_{\text {ini }}=373 \mathrm{~K}$ compared to $T_{\text {ini }}=353 \mathrm{~K}$, resulting in the proton conductivity of the Nafion membrane decreasing at $T_{\text {ini }}=373 \mathrm{~K}$. If the proton conductivity of the Nafion membrane decreases, the performance of the $\mathrm{O}_{2}$ reduction reaction drops due to a lack of proton. In addition, since the hydration of the Nafion membrane is not enough at $T_{\mathrm{ini}}=373 \mathrm{~K}$, the high $\mathrm{O}_{2}$ partial pressure is needed to progress the $\mathrm{O}_{2}$ reduction reaction [43]. As a result, it is thought that the amount of $\mathrm{O}_{2}$ consumption decreases at $T_{\text {ini }}=373 \mathrm{~K}$. The concentration over-potential increases with a decrease in the 
$\mathrm{O}_{2}$ consumption, resulting in the current density decreasing as $T_{\mathrm{ini}}=373 \mathrm{~K}$. In addition, the ohmic loss due to the proton conductivity of the Nafion membrane increases when thickness of the Nafion membrane increases [45]. Consequently, the current density in the case with Nafion 115 at $T_{\text {ini }}=373 \mathrm{~K}$ is smaller compared to the other conditions.

\subsection{Quantitative Evaluation along with the Gas Flow through the Gas Channel on Mass and Current Density on the Interface between Nafion Membrane and Cathode Catalyst Layer}

In order to investigate the effect of the Nafion membrane and $T_{\text {ini }}$ on the molar concentration distribution of $\mathrm{H}_{2} \mathrm{O}$ and the distribution of the current density, which can quantitatively indicate the performance of the electrochemical reaction in PEMFC, this study selected the analysis points of A to K, as shown in Figure 6. The average value on the cross sectional area of the interface between the Nafion membrane and cathode catalyst layer at each point, which covers both part under gas channel and that under rib, has been calculated.

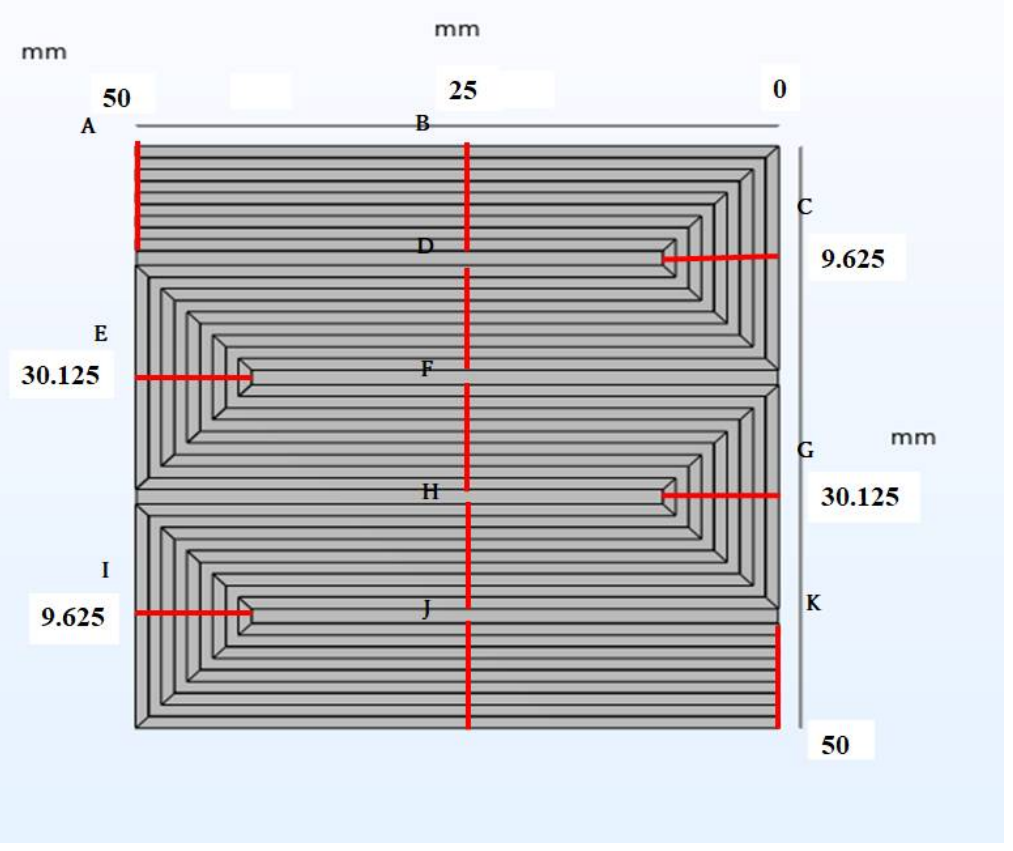

Figure 6. Analysis points for the quantitative evaluation along with the gas flow through the gas channel.

Figures 7-10 show comparisons of molar concentration of $\mathrm{H}_{2} \mathrm{O}$ along with the gas flow through the gas channel with different relative humidities of supply gas among different Nafion membranes and $T_{\text {ini, }}$, respectively. Tables $4-8$ list the values shown in Figures 7-10 to compare quantitatively, respectively. According to Figures 7-10, the molar concentration of $\mathrm{H}_{2} \mathrm{O}$ increases along with the gas flow through the gas channel, irrespective of the Nafion membrane thickness, $T_{\mathrm{ini}}$, and relative humidity of the supply gas. Since the $\mathrm{O}_{2}$ reduction reaction progresses along with the gas flow through the gas channel, $\mathrm{H}_{2} \mathrm{O}$, which is a product of the $\mathrm{O}_{2}$ reduction reaction, increases as expected. In addition, the molar concentration of $\mathrm{H}_{2} \mathrm{O}$ is the highest at $T_{\mathrm{ini}}=353 \mathrm{~K}$ among different $T_{\mathrm{ini}}$, irrespective of the Nafion membrane thickness and relative humidity of the supply gas. As described above, $T_{\text {ini }}=353 \mathrm{~K}$ is the most humidified condition among different $T_{\text {ini, }}$, irrespective of the Nafion membrane thickness and relative humidity of the supply gas, resulting in the proton conductivity of the Nafion membrane and the performance of $\mathrm{O}_{2}$ reduction reaction at cathode being the best. Consequently, the molar concentration of $\mathrm{H}_{2} \mathrm{O}$ is the highest at $T_{\mathrm{ini}}=353 \mathrm{~K}$ among the investigated $T_{\mathrm{ini}}$. Regarding the impact of the relative humidity of the supply gas, the molar concentration of $\mathrm{H}_{2} \mathrm{O}$ increases when the relative humidity of the supply gas increases, irrespective of the Nafion membrane thickness and 
$T_{\text {ini. }}$. The largest molar concentration of $\mathrm{H}_{2} \mathrm{O}$ is confirmed with $\mathrm{A} 80 \% \mathrm{RH} \& \mathrm{C} 80 \% \mathrm{RH}$, while the smallest molar concentration of $\mathrm{H}_{2} \mathrm{O}$ is confirmed with an anode of $40 \% \mathrm{RH}$ and cathode of $40 \% \mathrm{RH}$ (A40\%RH\&C40\%RH). Generally speaking, the increase in humidification enhances the performance of PEMFC, which promotes the proton conductivity of the Nafion membrane, while the decrease in proton conductivity of Nafion membrane causes higher ohmic losses [22,46]. As discussed above, with the low relative humidity, the ionomer in the cathode catalyst layer is hard to be saturated by the $\mathrm{H}_{2} \mathrm{O}$ migrated through the Nafion membrane from the anode to the cathode, deciding the performance of the $\mathrm{O}_{2}$ reduction reaction at the cathode, which produces $\mathrm{H}_{2} \mathrm{O}$ [40]. Consequently, it is obtained that the molar concentration of $\mathrm{H}_{2} \mathrm{O}$ is the largest with $\mathrm{A} 80 \% \mathrm{RH} \& \mathrm{C} 80 \% \mathrm{RH}$, while it is the smallest with $\mathrm{A} 40 \% \mathrm{RH} \& \mathrm{C} 40 \% \mathrm{RH}$. Comparing the thickness of the Nafion membrane, the molar concentration of $\mathrm{H}_{2} \mathrm{O}$ decreases when the thickness of the Nafion membrane increases, irrespective of $T_{\mathrm{ini}}$ and the relative humidity of the supply gas. In particular, the molar concentration of $\mathrm{H}_{2} \mathrm{O}$ for Nafion 115 is much smaller than that for the other Nafion membranes. $\mathrm{H}_{2} \mathrm{O}$ flux of PEM as well as the conductivity of the Nafion membrane is promoted when the thickness of the Nafion membrane decreases, particularly below $50 \mu \mathrm{m}[21,47,48]$, which corresponds to Nafion NRE-212 and Nafion NRE-211 in this study. In addition, the ohmic loss due to proton conductivity of Nafion membrane decreases when the thickness of Nafion membrane [49] decreases. Since the proton conductivity and $\mathrm{H}_{2} \mathrm{O}$ flux of Nafion membrane are low for a thick Nafion membrane, the performance of $\mathrm{O}_{2}$ reduction reaction, which produces $\mathrm{H}_{2} \mathrm{O}$ at the cathode, declines. Consequently, it is thought that the molar concentration of $\mathrm{H}_{2} \mathrm{O}$ decreases when the thickness of the Nafion membrane increases, especially for Nafion 115. Summarizing the above discussion, the largest molar concentration of $\mathrm{H}_{2} \mathrm{O}$, which is $15.1 \mathrm{~mol} / \mathrm{m}^{3}$, is obtained at the position $\mathrm{K}$ in the case of using Nafion NRE-211 at $T_{\text {ini }}=353 \mathrm{~K}$ with A $80 \%$ RH\&C $80 \% R H$ according to Tables 4-8. In this study, it is assumed that $\mathrm{H}_{2} \mathrm{O}$ is treated as a vapor. To validate this assumption, the saturation of $\mathrm{H}_{2} \mathrm{O}$ calculated by the numerical simulation of this study is confirmed. The saturation of $\mathrm{H}_{2} \mathrm{O}$ is defined by dividing a partial pressure of $\mathrm{H}_{2} \mathrm{O}$ vapor by a saturation $\mathrm{H}_{2} \mathrm{O}$ vapor pressure. Figure 11 shows a comparison of the saturation of $\mathrm{H}_{2} \mathrm{O}$ along with the gas flow through the gas channel among different Nafion membranes at $T_{\text {ini }}=353 \mathrm{~K}$ with A80\%RH\&C $80 \%$ RH. It is seen from Figure 11 that the saturation of $\mathrm{H}_{2} \mathrm{O}$ is lower than 1.0 even the case of Nafion NRE-211 near the outlet. When the saturation of $\mathrm{H}_{2} \mathrm{O}$ is lower than 1.0, it means that $\mathrm{H}_{2} \mathrm{O}$ exists as a vapor. The molar concentration of $\mathrm{H}_{2} \mathrm{O}$ is the largest in the case of Nafion NRE-211 under the condition that $T_{\text {ini }}=353 \mathrm{~K}$ with $\mathrm{A} 80 \% \mathrm{RH} \& \mathrm{C} 80 \% \mathrm{RH}$ among conditions investigated in this study. Therefore, it can be argued that $\mathrm{H}_{2} \mathrm{O}$ can be treated as a vapor under the conditions investigated in this study.

Table 4. Comparison of molar concentration of $\mathrm{H}_{2} \mathrm{O}$ along with the gas flow through the gas channel on the interface between Nafion membranes and cathode catalyst layer among different Nafion membranes and $T_{\text {ini }}$ (unit: $\mathrm{mol} / \mathrm{m}^{3} ; \mathrm{A} 80 \% \mathrm{RH} \& \mathrm{C} 80 \% \mathrm{RH}$ ).

\begin{tabular}{|c|c|c|c|c|c|c|c|c|c|c|c|}
\hline & A & B & $C$ & D & E & F & G & $\mathbf{H}$ & I & $\mathbf{J}$ & $\mathbf{K}$ \\
\hline \multicolumn{12}{|c|}{$353 \mathrm{~K}$} \\
\hline 115 & 0.721 & 2.07 & 3.14 & 4.27 & 5.22 & 6.25 & 7.12 & 8.05 & 8.85 & 9.61 & 10.3 \\
\hline 212 & 0.793 & 2.87 & 4.46 & 6.10 & 7.46 & 8.88 & 10.1 & 11.3 & 12.4 & 13.3 & 14.2 \\
\hline 211 & 0.813 & 3.08 & 4.81 & 6.57 & 8.02 & 9.53 & 10.8 & 12.1 & 13.2 & 14.2 & 15.1 \\
\hline \multicolumn{12}{|c|}{$363 \mathrm{~K}$} \\
\hline 115 & 0.955 & 2.23 & 3.23 & 4.28 & 5.18 & 6.13 & 6.96 & 7.84 & 8.59 & 9.31 & 9.93 \\
\hline 212 & 0.979 & 2.49 & 3.67 & 4.89 & 5.92 & 7.02 & 7.96 & 8.94 & 9.78 & 10.6 & 11.3 \\
\hline 211 & 0.981 & 2.51 & 3.70 & 4.93 & 5.97 & 7.08 & 8.02 & 9.01 & 9.85 & 10.6 & 11.3 \\
\hline \multicolumn{12}{|c|}{$373 \mathrm{~K}$} \\
\hline 115 & 1.17 & 1.58 & 1.91 & 2.27 & 2.58 & 2.93 & 3.23 & 3.56 & 3.85 & 4.13 & 4.38 \\
\hline 212 & 1.19 & 1.77 & 2.24 & 2.74 & 3.17 & 3.65 & 4.06 & 4.52 & 4.91 & 5.29 & 5.63 \\
\hline 211 & 1.20 & 1.86 & 2.39 & 2.95 & 3.45 & 3.98 & 4.45 & 4.95 & 5.40 & 5.82 & 6.20 \\
\hline
\end{tabular}



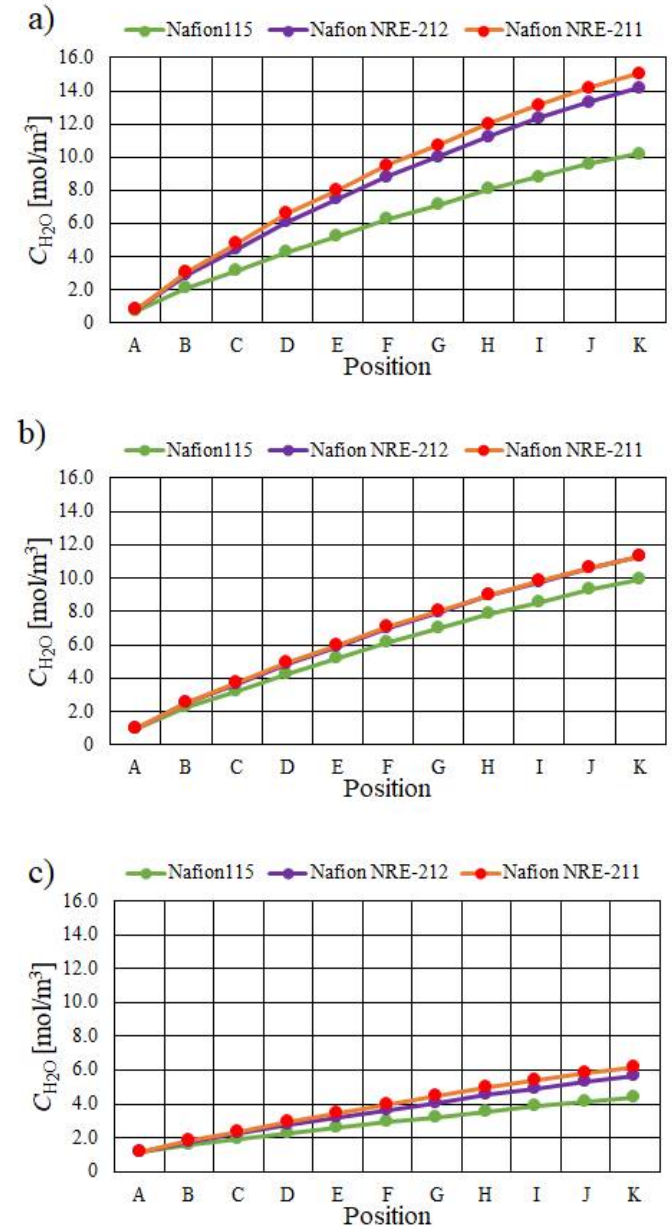

Figure 7. Comparison of molar concentration of $\mathrm{H}_{2} \mathrm{O}$ along with the gas flow through the gas channel on the interface between Nafion membranes and cathode catalyst layer among different Nafion membranes and $T_{\text {ini }}(A 80 \% R H \& C 80 \% R H ;(a): 353 \mathrm{~K}$, (b): $363 \mathrm{~K}$, (c): $373 \mathrm{~K})$.

Table 5. Comparison of molar concentration of $\mathrm{H}_{2} \mathrm{O}$ along with the gas flow through the. gas channel on the interface between Nafion membranes and cathode catalyst layer among different Nafion membranes and $T_{\text {ini }}$ (unit: $\mathrm{mol} / \mathrm{m}^{3} ; \mathrm{A} 80 \% \mathrm{RH} \& \mathrm{C} 40 \% \mathrm{RH}$ ).

\begin{tabular}{|c|c|c|c|c|c|c|c|c|c|c|c|}
\hline & A & B & C & D & E & F & G & $\mathbf{H}$ & I & $\mathbf{J}$ & K \\
\hline \multicolumn{12}{|c|}{$353 \mathrm{~K}$} \\
\hline 115 & 0.425 & 1.68 & 2.68 & 3.73 & 4.62 & 5.59 & 6.41 & 7.30 & 8.05 & 8.77 & 9.40 \\
\hline 212 & 0.477 & 2.28 & 3.68 & 5.13 & 6.35 & 7.63 & 8.71 & 9.85 & 10.8 & 11.7 & 12.5 \\
\hline 211 & 0.492 & 2.44 & 3.96 & 5.52 & 6.81 & 8.17 & 9.31 & 10.5 & 11.5 & 12.5 & 13.3 \\
\hline \multicolumn{12}{|c|}{$363 \mathrm{~K}$} \\
\hline 115 & 0.527 & 1.46 & 2.21 & 3.01 & 3.69 & 4.44 & 5.07 & 5.77 & 6.36 & 6.94 & 7.44 \\
\hline 212 & 0.557 & 1.80 & 2.78 & 3.81 & 4.68 & 5.63 & 6.43 & 7.29 & 8.02 & 8.72 & 9.33 \\
\hline 211 & 0.575 & 2.00 & 3.12 & 4.28 & 5.27 & 6.32 & 7.21 & 8.16 & 8.97 & 9.73 & 10.4 \\
\hline \multicolumn{12}{|c|}{$373 \mathrm{~K}$} \\
\hline 115 & 0.644 & 1.02 & 1.33 & 1.66 & 1.95 & 2.28 & 2.56 & 2.87 & 3.14 & 3.40 & 3.64 \\
\hline 212 & 0.664 & 1.25 & 1.72 & 2.23 & 2.67 & 3.16 & 3.57 & 4.03 & 4.43 & 4.82 & 5.16 \\
\hline 211 & 0.675 & 1.37 & 1.92 & 2.52 & 3.15 & 3.60 & 4.08 & 4.61 & 5.07 & 5.51 & 5.91 \\
\hline
\end{tabular}



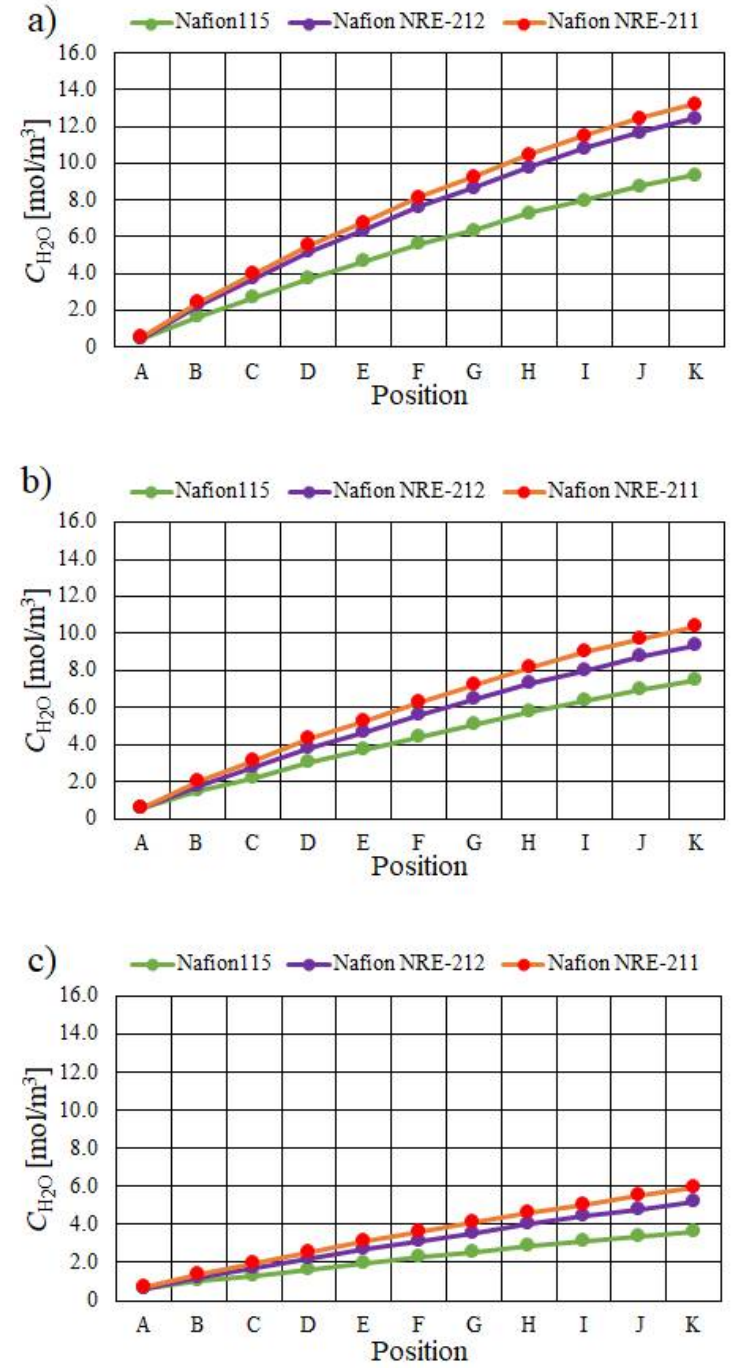

Figure 8. Comparison of molar concentration of $\mathrm{H}_{2} \mathrm{O}$ along with the gas flow through the gas channel on the interface between Nafion membranes and cathode catalyst layer among different Nafion membranes and $T_{\text {ini }}(A 80 \% R H \& C 40 \% R H ;(a): 353 \mathrm{~K},(\mathbf{b}): 363 \mathrm{~K}$, (c): $373 \mathrm{~K})$.

Table 6. Comparison of molar concentration of $\mathrm{H}_{2} \mathrm{O}$ along with the gas flow through the gas channel on the interface between Nafion membranes and cathode catalyst layer among different Nafion membranes and $T_{\text {ini }}$ (unit: $\mathrm{mol} / \mathrm{m}^{3} ; \mathrm{A} 40 \% \mathrm{RH} \& \mathrm{C} 80 \% \mathrm{RH}$ ).

\begin{tabular}{|c|c|c|c|c|c|c|c|c|c|c|c|}
\hline & A & B & C & D & E & F & G & $\mathbf{H}$ & I & $\mathbf{J}$ & $\mathbf{K}$ \\
\hline \multicolumn{12}{|c|}{$353 \mathrm{~K}$} \\
\hline 115 & 0.706 & 1.91 & 2.86 & 3.87 & 4.73 & 5.67 & 6.46 & 7.31 & 8.05 & 8.74 & 9.36 \\
\hline 212 & 0.758 & 2.49 & 3.83 & 5.23 & 6.40 & 7.64 & 8.69 & 9.79 & 10.7 & 11.6 & 12.4 \\
\hline 211 & 0.773 & 2.65 & 4.10 & 5.60 & 6.85 & 8.17 & 9.27 & 10.4 & 11.4 & 12.3 & 13.1 \\
\hline \multicolumn{12}{|c|}{$363 \mathrm{~K}$} \\
\hline 115 & 0.915 & 1.80 & 2.51 & 3.26 & 3.91 & 4.62 & 5.23 & 5.89 & 6.46 & 7.01 & 7.49 \\
\hline 212 & 0.945 & 2.12 & 3.05 & 4.03 & 4.86 & 5.76 & 6.53 & 7.35 & 8.06 & 8.73 & 9.32 \\
\hline 211 & 0.954 & 2.21 & 3.21 & 4.25 & 5.13 & 6.08 & 6.89 & 7.76 & 8.50 & 9.20 & 9.82 \\
\hline \multicolumn{12}{|c|}{$373 \mathrm{~K}$} \\
\hline 115 & 1.16 & 1.41 & 1.62 & 1.85 & 2.05 & 2.27 & 2.46 & 2.68 & 2.87 & 3.05 & 3.22 \\
\hline 212 & 1.18 & 1.70 & 2.11 & 2.55 & 2.94 & 3.37 & 3.74 & 4.15 & 4.50 & 4.85 & 5.15 \\
\hline 211 & 1.19 & 1.80 & 2.28 & 2.81 & 3.26 & 3.76 & 4.19 & 4.66 & 5.07 & 5.46 & 5.82 \\
\hline
\end{tabular}



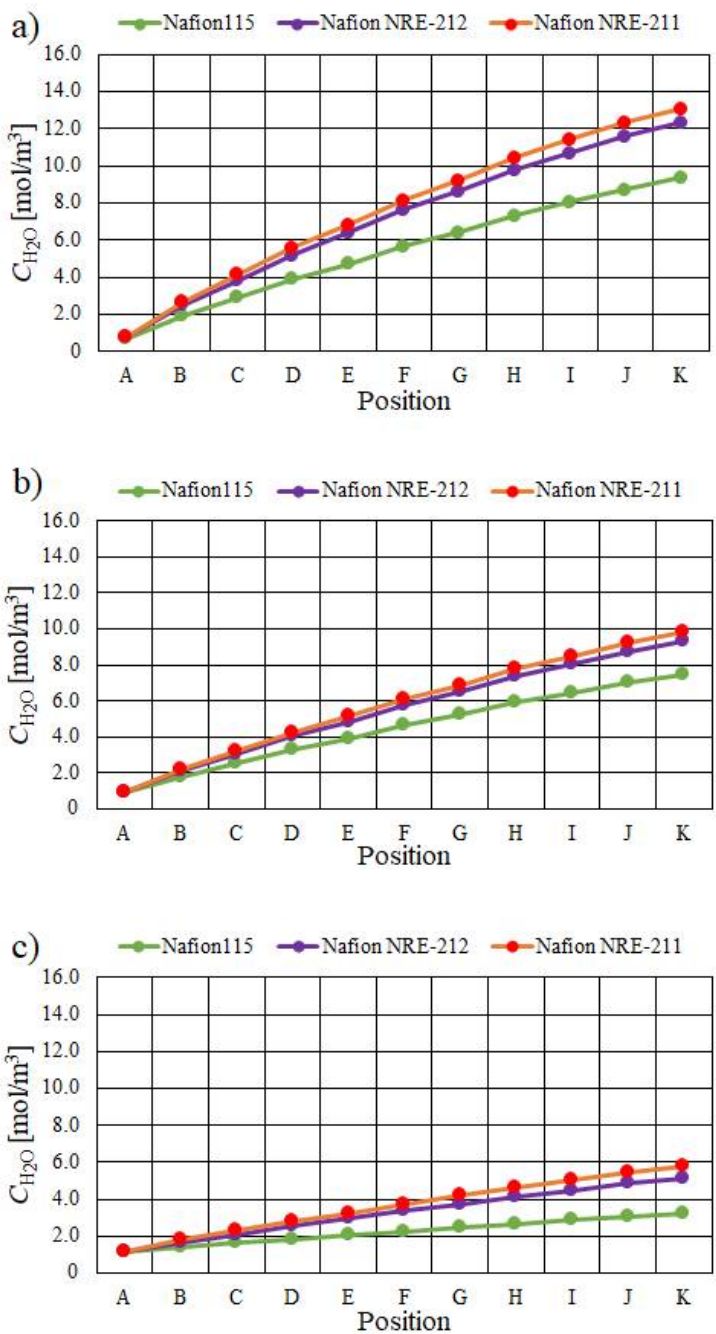

Figure 9. Comparison of molar concentration of $\mathrm{H}_{2} \mathrm{O}$ along with the gas flow through the gas channel on the interface between Nafion membrane and cathode catalyst layer among different Nafion membranes and $T_{\text {ini }}(\mathrm{A} 40 \% \mathrm{RH} \& \mathrm{C} 80 \% \mathrm{RH} ;(\mathbf{a}): 353 \mathrm{~K}$, (b): $363 \mathrm{~K}$, (c): $373 \mathrm{~K})$.

Table 7. Comparison of molar concentration of $\mathrm{H}_{2} \mathrm{O}$ along with the gas flow through the gas channel on the interface between Nafion membranes and cathode catalyst layer among different Nafion membranes and $T_{\text {ini }}$ (unit: $\mathrm{mol} / \mathrm{m}^{3} ; \mathrm{A} 40 \% \mathrm{RH} \& \mathrm{C} 40 \% \mathrm{RH}$ ).

\begin{tabular}{|c|c|c|c|c|c|c|c|c|c|c|c|}
\hline & A & B & $C$ & D & $\mathrm{E}$ & F & G & $\mathbf{H}$ & I & $\mathbf{J}$ & $\mathbf{K}$ \\
\hline \multicolumn{12}{|c|}{$353 \mathrm{~K}$} \\
\hline 115 & 0.368 & 1.01 & 1.54 & 2.11 & 2.59 & 3.13 & 3.60 & 4.11 & 4.56 & 4.99 & 5.37 \\
\hline 212 & 0.438 & 1.83 & 2.93 & 4.09 & 5.06 & 6.12 & 7.00 & 7.96 & 8.77 & 9.53 & 10.2 \\
\hline 211 & 0.453 & 2.00 & 3.22 & 4.50 & 5.56 & 6.71 & 7.67 & 8.70 & 9.57 & 10.4 & 11.1 \\
\hline \multicolumn{12}{|c|}{$363 \mathrm{~K}$} \\
\hline 115 & 0.464 & 0.727 & 0.944 & 1.18 & 1.39 & 1.62 & 1.82 & 2.04 & 2.24 & 2.43 & 2.60 \\
\hline 212 & 0.529 & 1.09 & 2.25 & 3.06 & 3.75 & 4.51 & 5.16 & 5.86 & 6.47 & 7.05 & 7.55 \\
\hline 211 & 0.539 & 1.59 & 2.43 & 3.32 & 4.08 & 4.90 & 5.61 & 6.37 & 7.02 & 7.64 & 8.18 \\
\hline \multicolumn{12}{|c|}{$373 \mathrm{~K}$} \\
\hline 115 & 0.615 & 0.693 & 0.757 & 0.828 & 0.890 & 0.960 & 1.02 & 1.09 & 1.15 & 1.21 & 1.26 \\
\hline 212 & 0.650 & 1.09 & 1.45 & 1.84 & 2.18 & 2.56 & 2.88 & 3.24 & 3.55 & 3.86 & 4.13 \\
\hline 211 & 0.657 & 1.16 & 1.57 & 2.01 & 2.40 & 2.82 & 3.19 & 3.60 & 3.90 & 4.29 & 4.59 \\
\hline
\end{tabular}





Figure 10. Comparison of molar concentration of $\mathrm{H}_{2} \mathrm{O}$ along with the gas flow through the gas channel on the interface between Nafion membrane and cathode catalyst layer among different Nafion membranes and $T_{\text {ini }}(A 40 \% R H \& C 40 \% R H ;(a): 353 \mathrm{~K},(\mathbf{b}): 363 \mathrm{~K},(\mathbf{c}): 373 \mathrm{~K})$.

Table 8. Comparison of current density along with the gas flow through the gas channel on the interface between Nafion membranes and cathode catalyst layer among different Nafion membranes and $T_{\text {ini }}$ (unit: $\mathrm{A} / \mathrm{mm}^{2} ; \mathrm{A} 80 \% \mathrm{H} \& \mathrm{C} 80 \% \mathrm{RH}$ ).

\begin{tabular}{cccccccccccc}
\hline & A & B & C & D & E & F & G & H & I & J & K \\
\hline \multicolumn{10}{c}{$353 \mathrm{~K}$} \\
\hline 115 & 0.197 & 0.194 & 0.192 & 0.190 & 0.187 & 0.185 & 0.182 & 0.180 & 0.178 & 0.175 & 0.173 \\
212 & 0.307 & 0.300 & 0.293 & 0.289 & 0.281 & 0.277 & 0.270 & 0.265 & 0.259 & 0.254 & 0.250 \\
211 & 0.336 & 0.328 & 0.320 & 0.314 & 0.305 & 0.299 & 0.291 & 0.286 & 0.277 & 0.272 & 0.266 \\
\hline \multicolumn{10}{c}{$363 \mathrm{~K}$} \\
\hline 115 & 0.197 & 0.193 & 0.191 & 0.189 & 0.186 & 0.184 & 0.181 & 0.179 & 0.176 & 0.174 & 0.172 \\
212 & 0.234 & 0.230 & 0.226 & 0.223 & 0.218 & 0.215 & 0.211 & 0.208 & 0.204 & 0.200 & 0.198 \\
211 & 0.237 & 0.232 & 0.228 & 0.225 & 0.220 & 0.217 & 0.212 & 0.209 & 0.205 & 0.201 & 0.198 \\
\hline & & & \multicolumn{10}{c}{$373 \mathrm{~K}$} & & & & & \\
\hline 115 & 0.066 & 0.065 & 0.065 & 0.065 & 0.064 & 0.064 & 0.063 & 0.063 & 0.062 & 0.062 & 0.062 \\
212 & 0.094 & 0.093 & 0.092 & 0.092 & 0.091 & 0.090 & 0.089 & 0.088 & 0.088 & 0.087 & 0.086 \\
211 & 0.107 & 0.106 & 0.105 & 0.104 & 0.103 & 0.102 & 0.101 & 0.100 & 0.099 & 0.098 & 0.097 \\
\hline
\end{tabular}




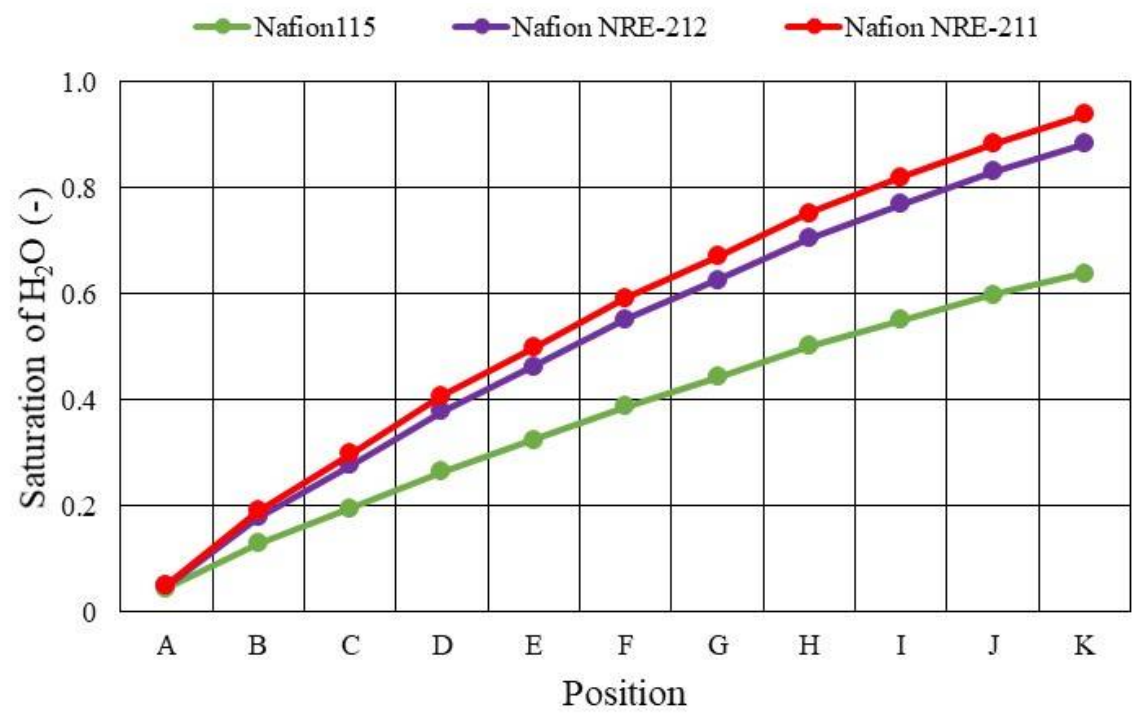

Figure 11. Comparison of saturation of $\mathrm{H}_{2} \mathrm{O}$ along with the gas flow through the gas channel among different Nafion membranes at $T_{\text {ini }}=353 \mathrm{~K}$ with $\mathrm{A} 80 \%$ RH\&C $80 \% \mathrm{RH}$.

Figures 12-15 show comparisons of current density along with the gas flow through the gas channel on the interface between the Nafion membrane and cathode catalyst layer changing the relative humidity of the supply gas among different Nafion membranes and $T_{\text {ini, }}$, respectively. Tables 8-12 list the values shown in Figures 12-15 to compare quantitatively, respectively. In addition, Table 12 summarizes the relationship between the current and voltage to compare the cell performance under the conditions investigated in this study. In this study, the data of the voltage, which were obtained at the constant current of $20 \mathrm{~A}$ under all conditions investigated in this study by the power generation experiment, were used as the initial condition for numerical simulation. Table 12 lists these data, which follow the tendencies shown in Figures 12-15. It is seen from Figures 12-15, since $\mathrm{H}_{2}$ and $\mathrm{O}_{2}$ are consumed along with the gas flow through the gas channel, the current density decreases along with the gas flow through the gas channel. With the decrease in the molar concentration of $\mathrm{H}_{2}$ and $\mathrm{O}_{2}$, i.e., the partial pressure of $\mathrm{H}_{2}$ and $\mathrm{O}_{2}$, the gas diffusion from gas channel to the interface between Nafion membrane and cathode catalyst layer declines, resulting in the increase in the concentration over-potential [50]. In addition, it is seen from these figures that the current density is higher with the decrease in $T_{\text {ini. }}$. As discussed above, a higher relative humidity increases the current density [40]. Since the actual relative humidity of gas in the cell is the highest at $T_{\text {ini }}=353 \mathrm{~K}$ among the investigated $T_{\mathrm{ini}}$, resulting in the current density being the highest at $T_{\mathrm{ini}}=353 \mathrm{~K}$. As to the impact of the relative humidity of the supply gas, the current density increases when the relative humidity of the supply gas increases, irrespective of the Nafion membrane thickness and $T_{\mathrm{ini}}$. The largest current density is confirmed with $\mathrm{A} 80 \% \mathrm{RH} \& \mathrm{C} 80 \% \mathrm{RH}$, while the smallest current density is confirmed with $\mathrm{A} 40 \% \mathrm{RH} \& \mathrm{C} 40 \% \mathrm{RH}$. The performance of PEMFC is enhanced with the increase in humidification by the promotion of proton conductivity of Nafion membrane, resulting in lower ohmic losses [22,46]. Therefore, it was revealed that the current density is the largest with $\mathrm{A} 80 \% \mathrm{RH} \& \mathrm{C} 80 \% \mathrm{RH}$, while it is the smallest with A40\%RH\&C40\%RH. According to Figures 12-15, it is known that the current density increases when the thickness of the Nafion membrane decreases. The thinner Nafion membrane provides lower ohmic losses, indicating that the proton transfers with a shorter distance to reach the cathode and the $\mathrm{H}_{2} \mathrm{O}$ produced in the cathode catalyst layer reaches the anode faster [49]. In addition, $\mathrm{H}_{2} \mathrm{O}$ flux of Nafion membrane as well as the conductivity of the Nafion membrane is promoted when the thickness of the Nafion membrane decreases, especially below $50 \mu \mathrm{m}[21,47,48]$, which corresponds to Nafion NRE-212 and Nafion NRE-211 in this study. Therefore, it is revealed that the current density increases when the thickness of Nafion membrane decreases, especially for Nafion 
NRE-212 and Nafion NRE-211. Summarizing the above discussion, the largest current density of $0.336 \mathrm{~A} / \mathrm{mm}^{2}$ is obtained at the position A in the case of using Nafion NRE-211 at $T_{\text {ini }}=353 \mathrm{~K}$ with $\mathrm{A} 80 \% \mathrm{RH} \& \mathrm{C} 80 \% \mathrm{RH}$ according to Tables 8-12.
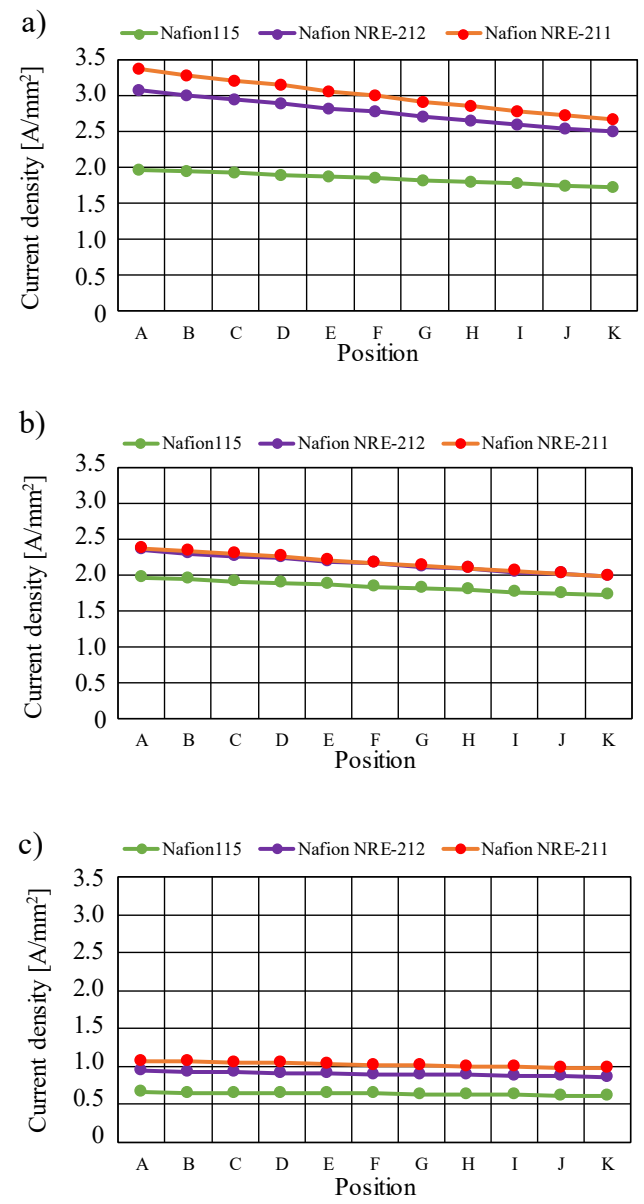

Figure 12. Comparison of current density along with the gas flow through the gas channel on the interface between Nafion membrane and cathode catalyst layer among different Nafion membranes and $T_{\text {ini }}(A 80 \%$ RH\&C80\%RH; (a): $353 \mathrm{~K},(\mathbf{b}): 363 \mathrm{~K},(\mathbf{c}): 373 \mathrm{~K})$.

Table 9. Comparison of current density along with the gas flow through the gas channel. on the interface between Nafion membranes and cathode catalyst layer among different Nafion membranes and $T_{\text {ini }}$ (unit: $\mathrm{A} / \mathrm{mm}^{2} ; \mathrm{A} 80 \% \mathrm{H} \& \mathrm{C} 40 \% \mathrm{RH}$ ).

\begin{tabular}{|c|c|c|c|c|c|c|c|c|c|c|c|}
\hline & A & B & C & D & E & F & G & $\mathbf{H}$ & I & $\mathbf{J}$ & K \\
\hline \multicolumn{12}{|c|}{$353 \mathrm{~K}$} \\
\hline 115 & 0.175 & 0.172 & 0.170 & 0.168 & 0.166 & 0.164 & 0.162 & 0.160 & 0.158 & 0.156 & 0.154 \\
\hline 212 & 0.253 & 0.248 & 0.244 & 0.240 & 0.235 & 0.231 & 0.226 & 0.223 & 0.218 & 0.214 & 0.211 \\
\hline 211 & 0.276 & 0.270 & 0.246 & 0.260 & 0.253 & 0.249 & 0.243 & 0.239 & 0.233 & 0.229 & 0.225 \\
\hline \multicolumn{12}{|c|}{$363 \mathrm{~K}$} \\
\hline 115 & 0.135 & 0.133 & 0.132 & 0.131 & 0.129 & 0.128 & 0.127 & 0.125 & 0.124 & 0.123 & 0.122 \\
\hline 212 & 0.180 & 0.178 & 0.175 & 0.173 & 0.170 & 0.168 & 0.165 & 0.163 & 0.160 & 0.158 & 0.156 \\
\hline 211 & 0.208 & 0.204 & 0.201 & 0.198 & 0.194 & 0.191 & 0.187 & 0.185 & 0.181 & 0.178 & 0.176 \\
\hline \multicolumn{12}{|c|}{$373 \mathrm{~K}$} \\
\hline 115 & 0.057 & 0.056 & 0.056 & 0.055 & 0.055 & 0.055 & 0.054 & 0.054 & 0.054 & 0.053 & 0.053 \\
\hline 212 & 0.088 & 0.087 & 0.086 & 0.086 & 0.085 & 0.084 & 0.083 & 0.083 & 0.082 & 0.081 & 0.081 \\
\hline 211 & 0.104 & 0.103 & 0.102 & 0.101 & 0.100 & 0.099 & 0.098 & 0.097 & 0.096 & 0.095 & 0.094 \\
\hline
\end{tabular}



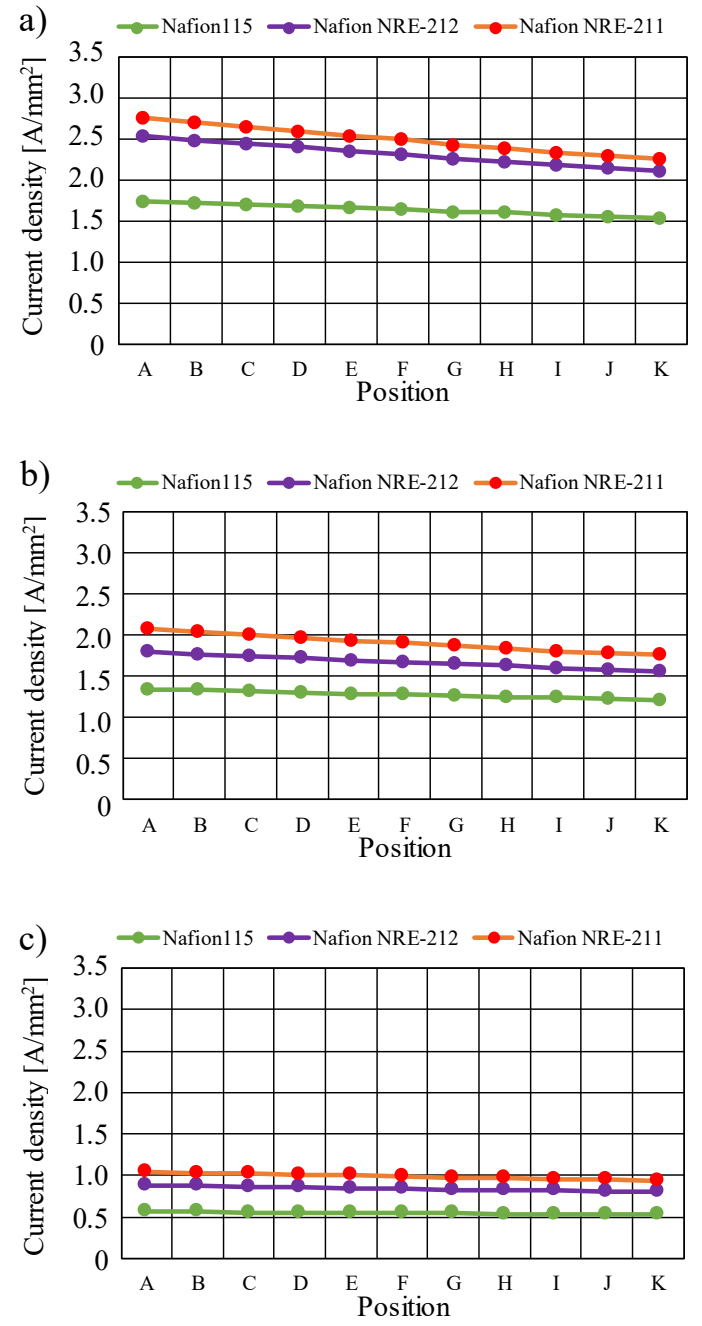

Figure 13. Comparison of current density along with the gas flow through the gas channel on the interface between Nafion membrane and cathode catalyst layer among different Nafion membranes and $T_{\text {ini }}(\mathrm{A} 80 \%$ RH\&C40\%RH; (a): $353 \mathrm{~K},(\mathbf{b}): 363 \mathrm{~K},(\mathbf{c}): 373 \mathrm{~K})$.

Table 10. Comparison of current density along with the gas flow through the gas channel on the interface between Nafion membranes and cathode catalyst layer among different Nafion membranes and $T_{\text {ini }}$ (unit: $\mathrm{A} / \mathrm{mm}^{2} ; \mathrm{A} 40 \% \mathrm{RH} \& \mathrm{C} 80 \% \mathrm{RH}$ ).

\begin{tabular}{|c|c|c|c|c|c|c|c|c|c|c|c|}
\hline & A & B & C & D & E & F & G & $\mathbf{H}$ & I & $\mathbf{J}$ & $\mathbf{K}$ \\
\hline \multicolumn{12}{|c|}{$353 \mathrm{~K}$} \\
\hline 115 & 0.175 & 0.173 & 0.171 & 0.169 & 0.167 & 0.165 & 0.163 & 0.161 & 0.159 & 0.157 & 0.155 \\
\hline 212 & 0.254 & 0.249 & 0.245 & 0.241 & 0.236 & 0.233 & 0.228 & 0.225 & 0.220 & 0.216 & 0.213 \\
\hline 211 & 0.277 & 0.270 & 0.265 & 0.261 & 0.255 & 0.251 & 0.245 & 0.241 & 0.235 & 0.231 & 0.227 \\
\hline \multicolumn{12}{|c|}{$363 \mathrm{~K}$} \\
\hline 115 & 0.136 & 0.134 & 0.133 & 0.132 & 0.130 & 0.132 & 0.128 & 0.127 & 0.125 & 0.124 & 0.123 \\
\hline 212 & 0.181 & 0.178 & 0.176 & 0.174 & 0.171 & 0.170 & 0.167 & 0.165 & 0.162 & 0.160 & 0.159 \\
\hline 211 & 0.195 & 0.192 & 0.189 & 0.187 & 0.183 & 0.181 & 0.178 & 0.176 & 0.173 & 0.170 & 0.168 \\
\hline \multicolumn{12}{|c|}{$373 \mathrm{~K}$} \\
\hline 115 & 0.041 & 0.041 & 0.041 & 0.041 & 0.040 & 0.040 & 0.040 & 0.040 & 0.039 & 0.039 & 0.039 \\
\hline 212 & 0.083 & 0.082 & 0.082 & 0.081 & 0.080 & 0.080 & 0.079 & 0.079 & 0.078 & 0.077 & 0.077 \\
\hline 211 & 0.098 & 0.097 & 0.096 & 0.096 & 0.095 & 0.094 & 0.093 & 0.092 & 0.091 & 0.091 & 0.090 \\
\hline
\end{tabular}



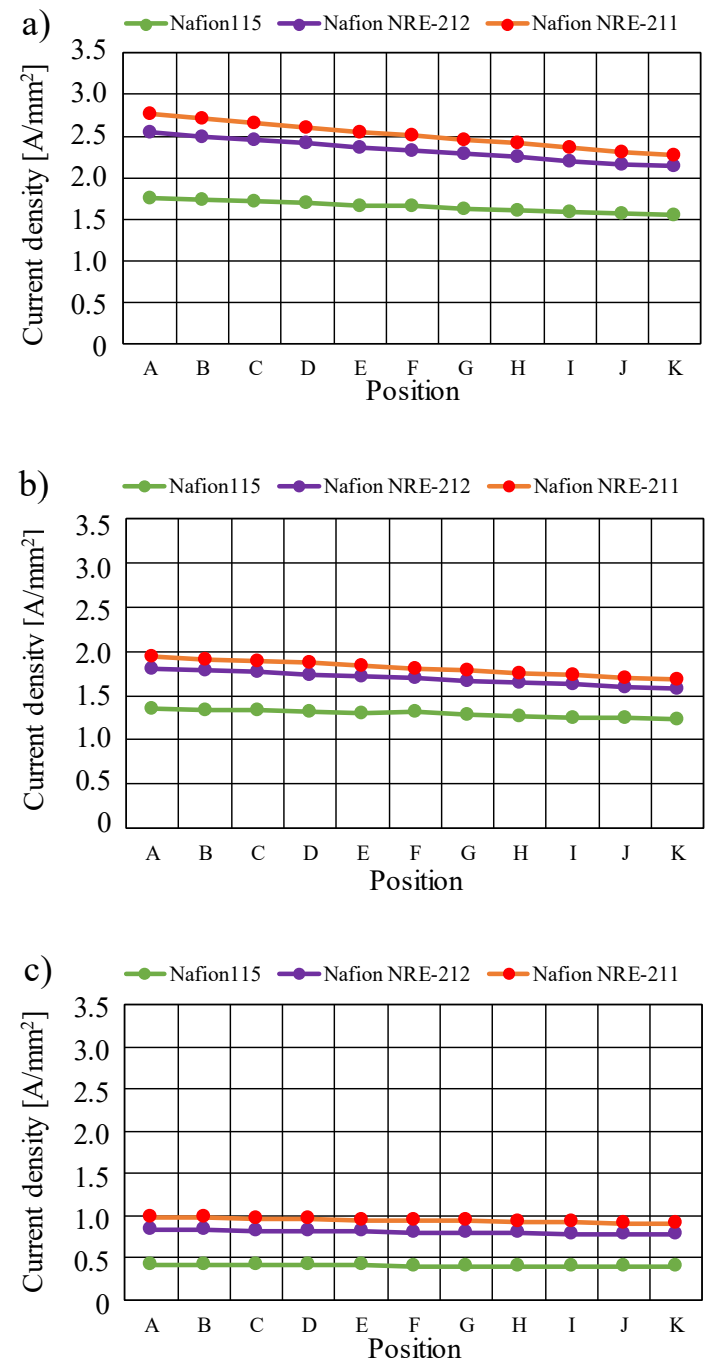

Figure 14. Comparison of current density along with the gas flow through the gas channel on the interface between Nafion membrane and cathode catalyst layer among different Nafion membranes and $T_{\text {ini }}(\mathrm{A} 40 \% \mathrm{H} \& \mathrm{C} 80 \% \mathrm{RH} ;(\mathbf{a}): 353 \mathrm{~K},(\mathbf{b}): 363 \mathrm{~K},(\mathbf{c}): 373 \mathrm{~K})$.

Table 11. Comparison of current density along with the gas flow through the gas channel on the interface between Nafion membrane and cathode catalyst layer among different Nafion membranes and $T_{\text {ini }}$ (unit: $\mathrm{A} / \mathrm{mm}^{2} ; \mathrm{A} 40 \% \mathrm{RH} \& \mathrm{C} 40 \% \mathrm{RH}$ ).

\begin{tabular}{cccccccccccc}
\hline & A & B & C & D & E & F & G & H & I & J & K \\
\hline \multicolumn{10}{c}{$353 \mathrm{~K}$} \\
\hline 115 & 0.089 & 0.088 & 0.088 & 0.087 & 0.086 & 0.086 & 0.085 & 0.085 & 0.084 & 0.083 & 0.083 \\
212 & 0.195 & 0.191 & 0.189 & 0.186 & 0.183 & 0.181 & 0.178 & 0.176 & 0.173 & 0.170 & 0.168 \\
211 & 0.218 & 0.214 & 0.210 & 0.207 & 0.203 & 0.200 & 0.196 & 0.194 & 0.190 & 0.190 & 0.184 \\
\hline \multicolumn{10}{c}{$363 \mathrm{~K}$} \\
\hline 115 & 0.038 & 0.037 & 0.037 & 0.037 & 0.037 & 0.037 & 0.037 & 0.036 & 0.036 & 0.036 & 0.036 \\
212 & 0.138 & 0.136 & 0.135 & 0.133 & 0.132 & 0.130 & 0.129 & 0.128 & 0.126 & 0.125 & 0.123 \\
211 & 0.153 & 0.151 & 0.149 & 0.147 & 0.145 & 0.143 & 0.141 & 0.140 & 0.138 & 0.136 & 0.135 \\
\hline & & & & \multicolumn{1}{c}{$373 \mathrm{~K}$} & & & & & \\
\hline 115 & 0.012 & 0.012 & 0.012 & 0.011 & 0.011 & 0.011 & 0.011 & 0.011 & 0.011 & 0.011 & 0.011 \\
212 & 0.066 & 0.066 & 0.065 & 0.065 & 0.064 & 0.064 & 0.064 & 0.063 & 0.062 & 0.062 & 0.062 \\
211 & 0.076 & 0.075 & 0.075 & 0.074 & 0.074 & 0.073 & 0.072 & 0.072 & 0.072 & 0.071 & 0.070 \\
\hline
\end{tabular}



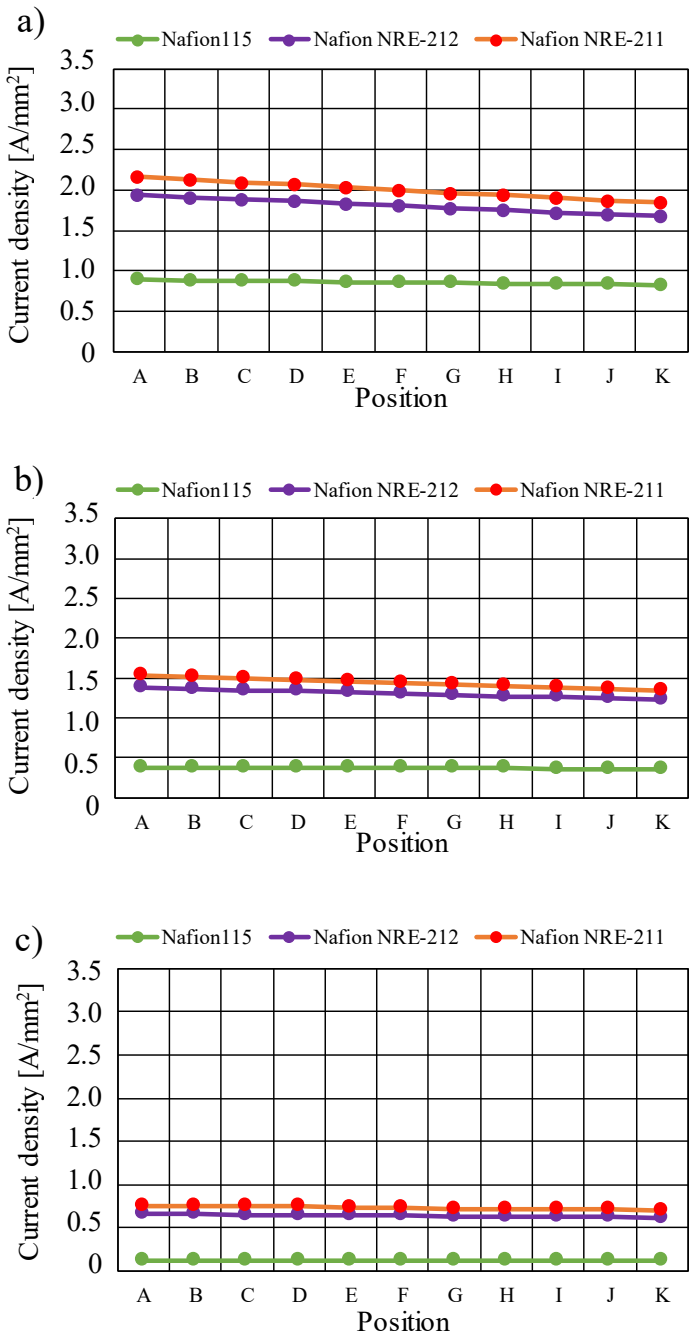

Figure 15. Comparison of current density along with the gas flow through the gas channel on the interface between Nafion membrane and cathode catalyst layer among different Nafion membranes and $T_{\text {ini }}(\mathrm{A} 40 \%$ RH\&C40\%RH; (a): $353 \mathrm{~K},(\mathbf{b}): 363 \mathrm{~K},(\mathbf{c}): 373 \mathrm{~K})$.

Considering the above results and discussion, this study can suggest that the thinner Nafion membrane under well-humidified conditions is desirable in order to obtain a higher power generation performance operated at higher temperatures such as $363 \mathrm{~K}$ and $373 \mathrm{~K}$. In addition, the uniform distribution of the current density along with the gas flow through the gas channel is obtained by using the thinner Nafion membrane according to Figures 12-15. However, the value of current density is still low at high temperatures such as $363 \mathrm{~K}$ and $373 \mathrm{~K}$, even using a thinner Nafion membrane. According to Tables 8-12, the current density is $0.237 \mathrm{~A} / \mathrm{mm}^{2}$ and $0.107 \mathrm{~A} / \mathrm{mm}^{2}$ at the position A in the case of using Nafion NRE- 211 at $T_{\text {ini }}=363 \mathrm{~K}$ and $373 \mathrm{~K}$ with $\mathrm{A} 80 \% \mathrm{RH} \& \mathrm{C} 80 \% \mathrm{RH}$, respectively. To increase the current density in the case of a thinner Nafion membrane, this study suggests the optimization of the catalyst layer [9], MPL [45], and gas channel flow of the gas separator [10], not only in order to control the mass and heat transfer phenomena but also to improve the electrochemical reaction. We have to consider the degradation of the Nafion membrane if we operate PEMFC at a higher temperature than usual. This study conducted the experimental investigation using a thin Nafion membrane at higher temperatures such as $363 \mathrm{~K}$ and $373 \mathrm{~K}$ [16]. In this experiment, it was confirmed that the thin Nafion membrane kept the performance over the power generation operation of $200 \mathrm{~h}$. However, it is necessary to investigate the characteristics of a thin Nafion membrane by operating for a longer time, e.g., $90,000 \mathrm{~h}(\fallingdotseq 10$ years), which is the target time according to the NEDO road map 2010 in Japan for the practical application of a PEMFC system. 
Table 12. Comparison of relationship between current of $20 \mathrm{~A}$ and voltage among investigated conditions in this study).

\begin{tabular}{|c|c|c|c|c|c|c|c|c|c|}
\hline \multicolumn{10}{|c|}{ A80\%RH\&C $80 \% R H$} \\
\hline$T_{\text {ini }}[\mathrm{K}]$ & & 353 & & & 363 & & & 373 & \\
\hline Nafion type & 115 & 212 & 211 & 115 & 212 & 211 & 115 & 212 & 211 \\
\hline Voltage [V] & 0.581 & 0.631 & 0.636 & 0.601 & 0.611 & 0.606 & 0.461 & 0.501 & 0.516 \\
\hline \multicolumn{10}{|c|}{ A80\%RH\&C40\%RH } \\
\hline$T_{\text {ini }}[\mathrm{K}]$ & & 353 & & & 363 & & & 373 & \\
\hline Nafion type & 115 & 212 & 211 & 115 & 212 & 211 & 115 & 212 & 211 \\
\hline Voltage [V] & 0.561 & 0.601 & 0.606 & 0.541 & 0.571 & 0.586 & 0.441 & 0.481 & 0.511 \\
\hline \multicolumn{10}{|c|}{ A40\%RH\&C $80 \%$ RH } \\
\hline$T_{\text {ini }}[\mathrm{K}]$ & & 353 & & & 363 & & & 373 & \\
\hline Nafion type & 115 & 212 & 211 & 115 & 212 & 211 & 115 & 212 & 211 \\
\hline Voltage [V] & 0.561 & 0.601 & 0.606 & 0.541 & 0.571 & 0.576 & 0.401 & 0.481 & 0.501 \\
\hline \multicolumn{10}{|c|}{ A $40 \%$ RH\&C $40 \%$ RH } \\
\hline$T_{\text {ini }}[\mathrm{K}]$ & & 353 & & & 363 & & & 373 & \\
\hline Nafion type & 115 & 212 & 211 & 115 & 212 & 211 & 115 & 212 & 211 \\
\hline Voltage [V] & 0.461 & 0.561 & 0.571 & 0.371 & 0.531 & 0.541 & 0.291 & 0.451 & 0.466 \\
\hline
\end{tabular}

\section{Conclusions}

The numerical simulation using a 3D model by multi-physics simulation software COMSOL Multiphysics has been conducted in order to investigate distributions of $\mathrm{H}_{2}, \mathrm{O}_{2}$, and $\mathrm{H}_{2} \mathrm{O}$ concentration and current density on the interface between Nafion the membrane and anode catalyst layer, and the interface between the Nafion membrane and cathode catalyst layer when operated at higher temperatures. The impacts of the Nafion membrane thickness, $T_{\mathrm{ini}}$, and relative humidity of the supply gas on these distributions have been investigated. The conclusions have been drawn as follows:

(i). The molar concentration of $\mathrm{H}_{2}$ and $\mathrm{O}_{2}$ decreases along with the gas flow through the gas channel, irrespective of the Nafion membrane thickness and $T_{\text {ini }}$.

(ii). The $\mathrm{O}_{2}$ consumption in the fuel cell is the largest at $T_{\mathrm{ini}}=353 \mathrm{~K}$, irrespective of Nafion membrane thickness.

(iii). The molar concentration of $\mathrm{H}_{2} \mathrm{O}$ increases along with the gas flow through the gas channel, irrespective of the Nafion membrane thickness and $T_{\mathrm{ini}}$, which can be explained by the $\mathrm{O}_{2}$ reduction reaction at cathode.

(iv). The current density decreases along with the gas flow through the gas channel, irrespective of Nafion membrane thickness and $T_{\text {ini }}$. The current density is the largest at $T_{\text {ini }}=353 \mathrm{~K}$, irrespective of the Nafion membrane thickness.

(v). The molar concentration of $\mathrm{H}_{2} \mathrm{O}$ increases when the relative humidity of the supply gas increases, irrespective of the Nafion membrane thickness and $T_{\text {ini }}$. The molar concentration of $\mathrm{H}_{2} \mathrm{O}$ is the largest with $\mathrm{A} 80 \% \mathrm{RH} \& \mathrm{C} 80 \% \mathrm{RH}$, while it is the smallest with $\mathrm{A} 40 \% \mathrm{RH} \& \mathrm{C} 40 \% \mathrm{RH}$.

(vi). The molar concentration of $\mathrm{H}_{2} \mathrm{O}$ generally decreases when the thickness of the Nafion membrane increases. The molar concentration of $\mathrm{H}_{2} \mathrm{O}$ for Nafion 115, whose thickness is $127 \mu \mathrm{m}$, is much smaller than that for the other thin Nafion membranes.

(vii). It is revealed that the largest molar concentration of $\mathrm{H}_{2} \mathrm{O}$ is $15.1 \mathrm{~mol} / \mathrm{m}^{3}$ near the outlet in the case of using Nafion NRE-211 at $T_{\text {ini }}=353 \mathrm{~K}$ with $\mathrm{A} 80 \% \mathrm{RH} \& \mathrm{C} 80 \% \mathrm{RH}$ among the conditions investigated in this study.

(viii). The current density is the highest at $T_{\text {ini }}=353 \mathrm{~K}$.

(ix). The current density increases when the relative humidity of the supply gas increases, irrespective of the Nafion membrane thickness and Tini, which indicates that the 
power generation performance is enhanced with the increase in relative humidity due to the promotion of proton conductivity of the Nafion membrane.

(x). The current density increases with the decrease in the Nafion membrane thickness since the $\mathrm{H}_{2} \mathrm{O}$ flux of the Nafion membrane as well as the conductivity of the Nafion membrane is promoted with the thinner Nafion membrane.

(xi). It is revealed that the largest current density is $0.336 \mathrm{~A} / \mathrm{mm}^{2}$ near the inlet in the case of using Nafion NRE-211 at $T_{\text {ini }}=353 \mathrm{~K}$ with $\mathrm{A} 80 \% \mathrm{RH} \& \mathrm{C} 80 \% \mathrm{RH}$ among the conditions investigated in this study.

(xii). This study reveals that the thinner Nafion membrane under well-humidified conditions is more desirable to obtain a higher power generation performance at higher temperatures, i.e., $363 \mathrm{~K}$ and $373 \mathrm{~K}$. Thinner Nafion membranes can provide a uniform distribution of current density as well.

(xiii). Since the current density at high temperatures of $363 \mathrm{~K}$ and $373 \mathrm{~K}$, which are $0.237 \mathrm{~A} / \mathrm{mm}^{2}$ and $0.107 \mathrm{~A} / \mathrm{mm}^{2}$, respectively, is still low, even using Nafion NRE-211 with $\mathrm{A} 80 \% \mathrm{RH} \& \mathrm{C} 80 \% \mathrm{RH}$, this study suggests the optimization of catalyst layer, MPL, and gas channel flow of gas separator in order to control the mass and heat transfer phenomena as well as to improve the electrochemical reaction.

Author Contributions: Conceptualization and writing-original draft preparation; A.N.; numerical analysis and investigation; K.T.; data curation; Y.K. and S.I.; writing-review and editing; E.H. All authors have read and agreed to the published version of the manuscript.

Funding: This research received no external funding.

Institutional Review Board Statement: Not applicable.

Informed Consent Statement: Not applicable.

Data Availability Statement: Not applicable.

Conflicts of Interest: The authors declare no conflict of interest.

\section{References}

1. NEDO (New Energy and Industry Technology Development Organization). Available online: http://www.nedo.go.jp/cotent/10 0871973 (accessed on 1 November 2021). (In Japanese)

2. Zhang, G.; Kandlikar, S.G.A. Critical Review of Cooling Technique in Proton Exchange Membrane Fuel Cell Stacks. Int. J. Hydrog. Energy 2012, 37, 2412-2429. [CrossRef]

3. Agbossou, K.; Kolhe, M.; Hamelin, J.; Bose, T.K. Performance of a Stand-Alone Renewable Energy System Based on Energy Storage as Hydrogen. IEEE Trans. Energy Convers. 2004, 19, 633-640. [CrossRef]

4. Li, Q.; He, R.; Jensen, J.O.; Bjerrum, N.J. Approaches and Recent Development Polymer Electrolyte Membrane for Fuel Cells Operating above $100{ }^{\circ} \mathrm{C}$. Chem. Mater. 2003, 15, 4896-4915. [CrossRef]

5. Lee, C.Y.; Wng, F.; Kuo, Y.W.; Tsai, C.H.; Cheng, Y.T.; Cheng, C.K.; Lin, J.T. In-situ Measurement of High-temperature Proton Exchange Membrane Fuel Cell Stack Using Flexible Five-in-one Micro Sensor. Sensors 2016, 16, 1731. [CrossRef] [PubMed]

6. Budak, Y.; Devrim, Y. Micro-cogeneration Application of a High-temperature PEM Fuel Cell Stack Operated with Polybenzimidazole Based Membranes. Int. J. Hydrog. Energy 2020, 45, 35198-35207. [CrossRef]

7. Jin, Y.; Wang, T.; Che, X.; Dong, J.; Liu, R.; Yang, J. New High-performance Bulky N-heterocyclic Group Functionalized Poly (Terphenyl Piperidinium) Membrane for HT-PEMFC Applications. J. Mem. Sci. 2022, 641, 119884. [CrossRef]

8. Lee, W.J.; Lee, J.S.; Park, H.Y.; Park, H.S.; Lee, S.Y.; Song, K.H.; Kim, H.J. Improvement of Fuel Cell Performances through the Enhanced Dispersion of the PTFE Binder in Electrodes for Use in High Temperature Polymer Electrolyte Membrane Fuel Cells. Int. J. Hydrog. Energy 2020, 45, 32825-32833. [CrossRef]

9. Xia, L.; Ni, M.; Xu, Q.; Xu, H.; Zheng, K. Optimization of Catalyst Layer Thickness for Achieving High Performance and Low Cost of High Temperature Proton Exchange Membrane Fuel Cell. Appl. Energy 2021, 291, 117012. [CrossRef]

10. Huang, T.; Wang, W.; Yuan, Y.; Huang, J.; Chen, X.; Zhang, J.; Kong, X.; Zhang, Y.; Wan, Z. Optimization of High-temperature Proton Exchange Membrane Fuel Cell Flow Channel Based on Genetic Algorithm. Energy Rep. 2021, 7, 1374-1384. [CrossRef]

11. Ghasabehi, M.; Shams, M.; Kanani, H. Multi-objective Optimization of Operating Conditions of an Enhanced Parallel Flow Filed Proton Exchange Membrane Fuel Cell. Energy Convers. Manag. 2021, 230, 113798. [CrossRef]

12. Das, S.K.; Gibson, H.A. Three Dimensional Multi-Physics Modeling and Simulation for Assessment of Mass Transport Impact on the Performance of a High Temperature Polymer Electrolyte Membrane Fuel Cell. J. Power Sources 2021, 499, 161-188. [CrossRef]

13. Xia, L.; Xu, Q.; He, Q.; Ni, M.; Seng, M. Numerical Study of High Temperature Proton Exchange Membrane Fuel Cell (HT-PEMFC) with a Focus on Rib Design. Int. J. Hydrog. Energy 2021, 46, 21098-21111. [CrossRef] 
14. Kanchan, B.K.; Randive, P.; Pati, S. Implications of Non-uniform Porosity Distribution in Gas Diffusion Layer on the Performance of a High Temperature PEM Fuel Cell. Int. J. Hydrog. Energy 2021, 46, 18571-18588. [CrossRef]

15. Nishimura, A.; Kamiya, S.; Okado, T.; Sato, Y.; Hirota, M.; Kolhe, M.L. Heat and Mass Transfer Analysis in Single Cell of PEFC Using Different PEM and GDL at Higher Temperature. Int. J. Hydrog. Energy 2019, 44, 29631-29640. [CrossRef]

16. Nishimura, A.; Okado, T.; Kojima, Y.; Hu, E. Impact of Microporous Layer on Heat and Mass Transfer in a Single Cell of Polymer Electrolyte Fuel Cell Using a Thin Polymer Electrolyte Membrane and a Thin Gas Diffusion Layer Operated at a High-temperature Range. ACS Omega 2021, 6, 14575-14584. [CrossRef] [PubMed]

17. Nishimura, A.; Kono, N.; Toyoda, K.; Kojima, Y.; Kolhe, M.L. Impact Analysis of MPL on a PEFC Cell's Temperature Distribution with Thin PEM and GDL for Operating at Higher Temperature than Usual. J. Energy Power Eng. 2021, 15, 39-51. [CrossRef]

18. Nishimura, A.; Fukuoka, H.; Yamamoto, K.; Okado, T.; Kojima, Y.; Hirota, M.; Kolhe, M.L. Numerical Analysis of Temperature Distributions in Single Cell of PEFC by Heat Transfer Model Considering Vapor Transfer. J. Energy Power Eng. 2020, 14, 1-15. [CrossRef]

19. Miao, T.; Tongsh, C.; Wang, J.; Cheng, P.; Liang, J.; Wang, Z.; Chen, W.; Zhang, C.; Xi, F.; Du, Q. Current Density and Temperature Distribution Measurement and Homogeneity Analysis for a Large-area Proton Exchange Membrane Fuel Cell. Energy 2022, 239, 121922. [CrossRef]

20. Han, C.; Jiang, T.; Shang, K.; Xu, B.; Chen, Z. Heat and Mass Transfer Performance of Proton Exchange Membrane Fuel Cells with Electrode of Anisotropic Thermal Conductivity. Int. J. Heat Mass Transf. 2022, 182, 121957. [CrossRef]

21. Springer, T.E.; Zawodzinski, T.A.; Gottsfeld, S. Polymer Electrolyte Fuel Cell Models. J. Electrochem. Soc. 1991, 138, 2334-2342. [CrossRef]

22. Penga, Z.; Tolj, I.; Barbir, F. Computational Fluid Dynamics Study of PEM Fuel Cell Performance. Int. J. Hydrog. Energy 2016, 41, 17585-17594. [CrossRef]

23. Yablecki, J.; Bazylak, A. Determining the Effective Thermal Conductivity of Composed PEMFC GDLs through Thermal Resistance Modeling. J. Power Sources 2012, 217, 470-478. [CrossRef]

24. Zhang, S.Y.; Qu, Z.G.; Xu, H.T.; Talkhoncheh, F.K.; Liu, S.; Gao, Q. A Numerical Study on the Performance of PEMFC with Wedge-shaped Fins in the Cathode Channel. Int. J. Hydrog. Energy 2021, 46, 27700-27708. [CrossRef]

25. Chen, H.; Guo, H.; Ye, F.; Ma, C.F. Improving Two-phase Mass Transportation under Non-Darcy Flow Effect in Orientated-type Flow Channels of Proton Exchange Membrane Fuel Cells. Int. J. Hydrog. Energy 2021, 46, 21600-21618. [CrossRef]

26. Chen, H.; Guo, H.; Ye, F.; Ma, C.F. A Numerical Study of Oriented-type Flow Channels with Porous-blocked Baffles of Proton Exchange Membrane Fuel Cells. Int. J. Hydrog. Energy 2021, 46, 29443-29458. [CrossRef]

27. Xia, L.; Ni, M.; He, Q.; Xu, Q.; Cheng, C. Optimization of Gas Diffusion Layer in High Temperature PEMFC with the Focuses on Thickness and Porosity. Appl. Energy 2021, 300, 117357. [CrossRef]

28. Freunberger, S.A.; Reum, M.; Evertz, J.; Wokaun, A.; Buchi, F.M. Measuring the Current Distribution in PEFCs with Sub-Millimeter Resolution. J. Electrochem. Soc. 2006, 153, A2158-A2165. [CrossRef]

29. Nishimura, A.; Sato, A.; Yoshimura, M.; Kamiya, S.; Hirota, M. Impact of Thickness of Polymer Electrolyte Membrane on Temperature Distribution in Single Cell of Polymer Electrolyte Fuel Cell Operated at High Temperature. J. Energy Power Eng. 2018, 12, 80-92. [CrossRef]

30. Nishimura, A.; Shibuya, K.; Morimoto, A.; Tanaka, S.; Hirota, M.; Nakamura, M.; Kojima, Y.; Narita, M.; Hu, E. Dominant Factor and Mechanism of Coupling Phenomena in Single Cell of Polymer Electrolyte Fuel Cell. Appl. Energy 2012, 1, 73-79. [CrossRef]

31. Cooper, N.J.; Santamaria, A.D.; Becton, M.K.; Park, J.W. Neutron Radiography Measurements of In-situ PEMFC Liquid Water Saturation in 2 D \& 3 D Morphology Gas Diffusion Layers. Int. J. Hydrog. Energy 2017, 42, 16269-16278.

32. The Japan Society of Mechanical Engineers. JSME Heat Transfer Handbook, 1st ed.; The Japan Society of Mechanical Engineers, Maruzen: Tokyo, Japan, 1993; p. 387.

33. Reid, R.C.; Prausnitz, J.M.; Poling, B.E. The Properties of Gases and Liquids, 1st ed.; McGraw-Hill: New York, USA, $1987 ;$ p. 591.

34. Merck. Available online: http://www.sigmaaldrich.com/japan/materialscience/alternative/nafion.html (accessed on 5 November 2021).

35. Senn, S.M.; Poulikakos, D. Polymer Electrolyte Fuel Cells with Porous Materials as Fluid Distributors and Comparisons with Traditional Channeled Systems. Trans. ASME 2004, 126, 410-418. [CrossRef]

36. Kang, K.; Ju, H. Numerical Modeling and Analysis of Micro-porous Layer Effects in Polymer Electrolyte Fuel Cells. J. Power Sources 2006, 194, 763-773. [CrossRef]

37. TORAY. Available online: http://www.torayca.com/en/lineup/composites/com_009_01.html (accessed on 5 November 2021).

38. Takayama, T. Numerical Simulation of Transient Internal States of PEFC Cell and Stack Considering Control of Anode System. Res. Rep. Mizuho Res. Technol. 2018, 9, 1-14.

39. Rostami, L.; Nejad, P.M.G.; Vatani, A. A Numerical Investigation of Serpentine Flow Channel with Different Bend Sizes in Polymer Electrolyte Membrane Fuel Cells. Energy 2016, 97, 400-410. [CrossRef]

40. Xing, L.; Das, P.K.; Song, X.; Mamlouk, M.; Scott, K. Numerical Analysis of the Optimum Membrane/Ionomer Water Content of PEMFCs: The Interface of Nafion Ionomer Content and Cathode Relative Humidity. Appl. Energy 2015, 138, 242-257. [CrossRef]

41. Jia, T.; Shen, S.; Zhao, J.; Jin, J.; Pan, B.; Duan, X.; Meng, C.; Che, Q. Ultrathin Membranes Formation via the Layer by Layer Self-assembly of Carbon Nanotubes-based Inorganics as High Temperature Proton Exchange Membranes. Int. J. Hydrog. Energy 2020, 45, 14517-14527. [CrossRef] 
42. Wong, C.Y.; Wong, W.Y.; Ramya, K.; Khalid, M.; Loh, K.S.; Daud, W.R.W.; Lim, K.L.; Walvekar, R.; Kadhum, A.A.H. Additives in Proton Exchange Membranes for Low- and High-temperature Fuel Cell Applications: A Review. Int. J. Hydrog. Energy 2019, 44, 6116-6135. [CrossRef]

43. Akitomo, F.; Sasabe, T.; Yoshida, T.; Naito, H.; Kawamura, K.; Hirai, S. Investigation of Effects of High Temperature and Pressure on a Polymer Electrolyte Fuel Cell with Polarization Analysis and X-ray Imaging of Liquid Water. J. Power Sources 2019, 431, 205-209. [CrossRef]

44. Kim, D.H.; Min, C.M.; Lee, E.; Lee, J.S.; Pal, C. Effect of Vinylphosphonic Acid and Polymer Binders with Phosphate Groups on Performance of High-temperature Polymer Electrolyte Membrane Fuel Cell. Catal. Today 2020, 358, 333-337. [CrossRef]

45. Fu, X.; Li, T.; Tang, L.; Deng, X.; Zhang, R.; Hu, S.; Zhao, F.; Li, X.; Liu, Q. Reticulated Polyaniline Nanowires as a Cathode Microporous Layer for High-temperature PEMFCs. Int. J. Hydrog. Energy 2021, 46, 8802-8809. [CrossRef]

46. Abdin, Z.; Webb, C.J.; Gray, E.M. PEM Fuel Cell Model and Simulation in Matlab-Simulink Based on Physical Parameters. Energy 2016, 116, 1131-1144. [CrossRef]

47. Mohanta, P.K.; Ripa, M.S.; Regnet, F.; Jorissen, L. Impact of Membrane Types and Catalyst Layers Composition on Performance of Polymer Electrolyte Membrane Fuel Cells. Chem. Open 2020, 9, 607-615. [CrossRef] [PubMed]

48. Rakhshanpouri, S.; Rowshanzamir, S. Water Transport through a PEM (Proton Exchange Membrane) Fuel Cell in a Seven-layer Model. Energy 2013, 50, 220-231. [CrossRef]

49. Ferreira, R.B.; Falcao, D.S.; Oliveira, V.B.; Pinto, A.M.F.R. Experimental Study on the Membrane Electrode Assembly of a Proton Exchange Membrane Fuel Cell: Effects of Microporous Layer, Membrane Thickness and Gas Diffusion Layer Hydrophobic Treatment. Electrochim. Acta 2017, 224, 337-345. [CrossRef]

50. Xu, B.; Li, D.; Ma, Z.; Zheng, M.; Li, Y. Thermodynamic Optimization of a High Temperature Proton Exchange Membrane Fuel Cell for Fuel Cell Vehicle Applications. Mathematics 2021, 9, 1792. [CrossRef] 